\title{
APASL consensus statements and recommendations for hepatitis C prevention, epidemiology, and laboratory testing
}

\author{
Masao Omata ${ }^{1,2} \cdot$ Tatsuo Kanda $^{3} \cdot$ Lai Wei $^{4} \cdot$ Ming-Lung $\mathrm{Yu}^{5} \cdot$ Wang-Long Chuang ${ }^{6} \cdot$ \\ Alaaeldin Ibrahim ${ }^{7} \cdot$ Cosmas Rinaldi Adithya Lesmana $^{8} \cdot$ Jose Sollano $^{9}$. \\ Manoj Kumar $^{10}$ - Ankur Jindal ${ }^{10}$ • Barjesh Chander Sharma ${ }^{11}$ - Saeed S. Hamid ${ }^{12}$. \\ A. Kadir Dokmeci ${ }^{13}$ - Mamun Al-Mahtab ${ }^{14}$ - Geofferey W. McCaughan ${ }^{15}$. \\ Jafri Wasim $^{12}$ • Darrell H. G. Crawford ${ }^{16}$ • Jia-Horng Kao ${ }^{17}$ • Osamu Yokosuka ${ }^{3}$. \\ George K. K. Lau ${ }^{18} \cdot$ Shiv Kumar Sarin ${ }^{10}$
}

Received: 17 February 2016/ Accepted: 20 April 2016/Published online: 26 May 2016

(c) The Author(s) 2016. This article is published with open access at Springerlink.com

\begin{abstract}
The Asian Pacific Association for the Study of the Liver (APASL) convened an international working party on "APASL consensus statements and recommendations for management of hepatitis C" in March 2015 to revise the "APASL consensus statements and management algorithms for hepatitis C virus infection" (Hepatol Int 6:409-435, 2012). The working party consisted of expert hepatologists from the Asian-Pacific region gathered at the Istanbul Congress Center, Istanbul, Turkey on 13 March 2015. New data were presented, discussed, and debated
\end{abstract}

Electronic supplementary material The online version of this article (doi:10.1007/s12072-016-9736-3) contains supplementary material, which is available to authorized users.

Masao Omata

momata-tky@umin.ac.jp

1 Yamanashi Prefectural Central Hospital, 1-1-1 Fujimi, Kofu-shi, Yamanashi 400-8506, Japan

2 The University of Tokyo, 7-3-1 Hongo, Bunkyo-ku, Tokyo 113-8655, Japan

3 Graduate School of Medicine, Chiba University, Chiba, Japan

4 Peking University People's Hospital, Peking University Hepatology Institute, Beijing, China

5 Kaohsiung Municipal Ta-Tung Hospital, Kaohsiung, Taiwan

6 Hepatobiliary Division, Department of Internal Medicine, Kaohsiung Medical University Hospital, Kaohsiung Medical University, Kaohsiung, Taiwan

7 GI/Liver Division, Department of Internal Medicine, University of Benha, Banha, Egypt

8 Digestive Disease and GI Oncology Center, Medistra Hospital, University of Indonesia, Jakarta, Indonesia

9 University Santo Tomas Hospital, Manila, Philippines during the course of drafting a revision. Participants of the consensus meeting assessed the quality of the cited studies. The finalized recommendations for hepatitis $\mathrm{C}$ prevention, epidemiology, and laboratory testing are presented in this review.

\section{Introduction}

The prevalence rates of hepatitis C virus (HCV) and HCV genotype (GT) distribution around the Asia-Pacific region were well described in a recent study [1]. Estimated HCV infection rates in the general populations were $0.1-14.7 \%$

10 Department of Hepatology, Institute of Liver and Biliary Sciences, New Delhi, India

11 Department of Gastroenterology, G.B. Pant Hospital, New Delhi, India

12 Department of Medicine, Aga Khan University and Hospital, Stadium Road, Karachi 74800, Pakistan

13 Department of Gastroenterology, Ankara University School of Medicine, Ankara, Turkey

14 Department of Hepatology, Bangabandhu Sheikh Mujib Medical University, Dhaka 1000, Bangladesh

15 Royal Prince Alfred Hospital, Centenary Institute, University of Sydney, Sydney, Australia

16 University of Queensland, School of Medicine, Woolloongabba, QLD 4102, Australia

17 National Taiwan University College of Medicine and National Taiwan University Hospital, Taipei, Taiwan

18 The Institute of Translational Hepatology, Beijing 302 Hospital, Beijing, China 
in the Asia-Pacific region [1]. HCV GTs vary, such as HCV GT-1, GT-2, GT-3, and other GTs, in the AsiaPacific region [1]. The absolute numbers of currently HCVinfected both globally and in the Asia-Pacific region may recently have been scaled down, since better seroprevalence studies demonstrated lower rates of active infection in China than previously believed [2,3]. In this article, we mainly aim to introduce the natural history of $\mathrm{HCV}$ infection and recent advances in hepatitis $\mathrm{C}$ prevention, epidemiology, and laboratory testing in Asian-Pacific countries. Grading of evidence and recommendations are shown in Supplementary Table 1.

\section{Natural history of HCV infection}

The natural history of hepatitis $\mathrm{C}$ is quite variable. The majority of patients who acquire HCV do not spontaneously clear the virus and develop chronic HCV infection. Chronic infection results in liver fibrosis and ultimately cirrhosis in a subset of patients, although the rate of disease progression is variable. Patients who develop cirrhosis are at further risk for complicating events (such as variceal hemorrhage, ascites, and encephalopathy) and hepatocellular carcinoma, although many patients with compensated cirrhosis remain stable for years $[4,5]$.

\section{Acute HCV infection}

Around 3-4 million people are newly infected with hepatitis $\mathrm{C}$ annually, and this phenomenon is not limited to developing countries, as 18,000 new HCV infections occur annually in the USA alone [6]. Populations at risk for acute hepatitis $\mathrm{C}$ are patients who received blood transfusions, blood products or anti-D-immunoglobulin during pregnancy prior to routine screening of blood products for $\mathrm{HCV}$, intravenous drug users, intranasal cocaine users, patients with tattoos or body piercings, healthcare workers, dialysis patients, and those involved in high-risk sexual activities. The introduction of routine screening of blood products and sterile injection needles has changed the principal cohorts of newly infected patients in developed countries, although these factors are still the leading cause of newly acquired HCV infection in Asian countries [7].

Acute hepatitis $\mathrm{C}$ infection is infrequently diagnosed because most patients are asymptomatic. Approximately $20-30 \%$ of adults may develop clinical symptoms, which are usually mild and nonspecific. Onset of symptoms occurs 3-12 weeks after exposure. Symptoms may include malaise, weakness, anorexia, and jaundice. Jaundice appears in only $15-20 \%$ of acutely infected individuals, and fulminant liver failure is rare except in those with concomitant chronic hepatitis B infection [8].
$\mathrm{HCV}$ RNA can be detected in the serum within 1-2 weeks after exposure. The level of HCV RNA rises rapidly during the first few weeks and then peaks between $10^{5}$ and $10^{7} \mathrm{IU} / \mathrm{mL}$, shortly before the peak of serum alanine aminotransferase (ALT) levels and onset of symptoms [9]. Serum ALT levels start rising 2-8 weeks postexposure and often reach levels more than 10 times the normal upper limits. Anti-HCV antibodies (anti-HCV), as detected by enzyme-linked immunosorbent assay (ELISA), become positive near the onset of symptoms, approximately 1-3 months after exposure. Up to $30 \%$ of patients will test negative for anti-HCV at the onset of their symptoms, making anti-HCV testing unreliable for diagnosis of acute infection. Almost all patients eventually develop antibodies; however, titers can be low or undetectable in immunodeficient patients. Approximately $10-15 \%$ of subjects may have fluctuating infection, with marked variation in the levels of ALT in association with marked changes in HCV RNA levels, including periods of HCV RNA negativity followed by reappearance of HCV RNA. In most patients, fluctuations are present only during the first 24 weeks after exposure, but they may also continue beyond 24 weeks [10].

The risk of chronic infection after hepatitis $\mathrm{C}$ acquisition is high because the virus has a tendency toward rapid mutation, leading to extensive viral diversity among the viral population infecting a single host. This can contribute to viral persistence because the viral diversity allows $\mathrm{HCV}$ to escape immune recognition [11]. In most studies, $50-85 \%$ of patients chronically remain HCV RNA positive following infection and seroconversion, depending on the population and the source of infection. These studies are heterogeneous in terms of their study populations, and the majority are clinic-based acute hepatitis $\mathrm{C}$ case series using descriptive methodologies. Discrepancies in these estimates have been attributed to a number of factors. First, the asymptomatic nature of early infection means that detection of acute infection is uncommon. Second, there are currently no diagnostic tests to differentiate between acute and chronic infection. Third, the majority of HCV infections occur in marginalized populations, such as injecting drug users (IDUs), who may be difficult to recruit into studies and maintain in follow-up. Finally, the statistical methods and definitions used to determine clearance estimates vary among studies. Of those who are able to spontaneously clear $\mathrm{HCV}$, most do so within 12 weeks of seroconversion, although spontaneous clearance after a longer period of follow-up has also been described [12]. The HCV RNA clearance rate is higher when clearance is defined as a single negative HCV RNA result compared with two negative HCV RNA results, which should be the preferred definition of RNA clearance [13]. High spontaneous HCV clearance in the Asia-Pacific region may be 
due to the high prevalence of the favorable IL28B genotype [14].

\section{Effects of treatment of acute hepatitis $C$}

The transition between acute hepatitis $\mathrm{C}$ and its progression to chronic HCV infection is poorly defined. Reported estimates of time to clearance range from 1-2 weeks up to 1-3 years. Although treatment is indicated in acutely infected patients likely to develop chronic HCV, the acute phase is frequently unrecognized. Peginterferon with or without ribavirin for 24 weeks induces high rates of viral clearance [15]. Response rates are lower in patients treated more than 20 weeks postinfection, and it is often recommended to initiate the therapy if HCV RNA remains positive after 12 weeks of observation. This strategy also negates the risk of loss to follow-up in at-risk patients. Newer antiviral agents may alter this thinking $[4,5]$.

\section{Chronic HCV infection}

There have been extensive studies focusing on the natural course of the disease progression of chronic hepatitis $\mathrm{C}$, including fibrosis progression and the development of cirrhosis and hepatocellular carcinoma (HCC).

\section{Natural progression of liver disease in chronic HCV infection}

The natural history of chronic HCV is described variably. Published estimates of fibrosis progression and time to cirrhosis are dependent on the study design and the patient population investigated. Retrospective studies have often been based on large tertiary referral centers and may reflect ascertainment bias because individuals with advanced liver disease are more likely to be referred. The timing of the initial infection is based on the patient's recall of first contact with blood products or intravenous drug abuse, which can often be inaccurate. In retrospective studies, cirrhosis rates have been reported to be between 17 and $55 \%, \mathrm{HCC}$ rates 1 and $23 \%$, and liver-related death 1 and $23 \%$ over an estimated infection period of 20-30 years $[16,17]$. Additionally, estimates from retrospective studies (17-55\%) have been higher than those from prospective studies (7-16\%), possibly reflecting referral bias in the former. Even prospective studies are limited by relatively short follow-up periods and are only available in well-defined patient cohorts, thus failing to provide information on longer-term outcomes. These studies typically show lower complication rates, as shown in a cohort of female infected with hepatitis $\mathrm{C}$ following administration of anti-D-immunoglobulin during pregnancy. Over a follow-up period of 18-20 years, the incidence of histologically confirmed cirrhosis was reported to be between 1 and $2 \%$, and bridging fibrosis between 2 and $10 \%$ [18]. An alternative approach is retrospective prospective studies in which the precise time at which past infection with acute hepatitis $\mathrm{C}$ occurred can be defined retrospectively and the subjects are subsequently followed prospectively. In early retrospective prospective studies, the interval from exposure ranged from 9 to 50 years, and development of cirrhosis occurred in $0.3-15 \%$ of patients, HCC developed in $0-1.9 \%$, and liver-related death occurred in 0-2.8\% [19]. Cumulatively, these studies suggest that there is a variable rate of disease progression to cirrhosis and its complications, likely due to multiple factors. Genomewide association studies revealed variants associated with the progression of liver fibrosis in HCV-infected patients [20, 21]. Further studies will be needed to clarify this point.

The progression of chronic hepatitis $\mathrm{C}$ is accelerated in human immunodeficiency virus (HIV)-infected patients. Hepatitis C and HIV can share routes of transmission. Coinfection with HIV has a negative impact on the natural history of HCV. Among those with persistent HCV infection, HIV coinfection has been associated with higher HCV plasma RNA viral loads and, according to most studies, with more rapid progression to cirrhosis, liver failure, and HCC. In a meta-analysis of eight cohorts of HIV/HCVcoinfected individuals, Graham et al. [22] demonstrated that HIV coinfection increased the risk of cirrhosis by a factor of 2.1 and clinically decompensated liver disease by a factor of 6.1 .

\section{Development of cirrhosis and its complications}

HCV infection causes slowly progressive disease characterized by persistent hepatic inflammation, leading to development of cirrhosis in approximately $10-20 \%$ of patients over 20-30 years of HCV infection. However, the published data vary considerably, with reported progression rates to cirrhosis from as low as $2-3 \%$ to as high as $51 \%$ over 22 years [23, 24]. The progression to cirrhosis is often clinically silent, and some patients are not known to have HCV infection until they present with the complications of end-stage liver disease. Cirrhosis rates begin to become significant after 20 years of infection. The time from HCV infection to cirrhosis depends on multiple factors and cannot be predicted in an individual patient. Multiple studies have attempted to measure the time interval from infection to cirrhosis and HCC. Frequently, the initial time of infection is not known and therefore must be estimated. Individuals who contracted HCV through a single blood transfusion or surgery are able to provide more precise time intervals from infection to cirrhosis and HCC. Although the mean time to cirrhosis in chronic HCV patients is estimated at 20 years, only $10-20 \%$ of patients 
will actually develop cirrhosis within this time period [25]. A systematic review of 111 studies analyzing the natural history of $\mathrm{HCV}$ estimated that the prevalence of cirrhosis 20 years after infection was $16 \% \quad[95 \%$ confidence interval (CI) 14-90\%] [26]. Overall, once cirrhosis has developed, there is a 1-5\% annual risk of $\mathrm{HCC}$ and a 3-6 \% annual risk of hepatic decompensation. Five- and ten-year survival rates of compensated cirrhosis are 90-95 and 70-80\%, respectively. The cumulative probability of an episode of clinical decompensation is 5-10\% at 1 year, increasing to $30-40 \%$ at 10 years from the diagnosis of cirrhosis. Once decompensated cirrhosis occurs, the 5-year survival rate falls to 40-50\% [27]. Achievement of viral eradication is associated with a marked decrease in decompensation and the incidence of bacterial infection [28].

\section{Development of $\mathrm{HCC}$}

The risk of HCC occurrence varies among HCV patients. It is a function of the degree of liver fibrosis and the time after acquisition of the infection. In a meta-analysis of 21 case-control studies, the risk for HCC increased 17-fold in $\mathrm{HCV}$-infected patients compared with HCV-negative controls [29]. Virtually all cases of HCV-related HCC occur among patients with cirrhosis. Once cirrhosis is established, HCC develops at an annual rate of $1-4 \%$ and is increased in patients with raised alpha-fetoprotein levels at baseline. Higher estimates, in the range of 5-7\%, have been reported from Japan. The higher proportion of elderly patients infected with $\mathrm{HCV}$ in Japan may explain the higher incidence rate in that country because older age accelerates the development of HCC. Patients with lower degrees of fibrosis exhibit $\mathrm{HCC}$ development at rates of $0.5-2.6 \%$ [30]. In the Hepatitis C Antiviral Long-term Treatment against Cirrhosis (HALT-C) trial, the overall rate of $\mathrm{HCC}$ development in cirrhotic patients was $7 \%$ over 4.8 years. Importantly, a significant number of patients with Ishak grade 3 or 4 fibrosis also developed $\mathrm{HCC}$, raising questions regarding what defines the need for screening in cirrhotic and noncirrhotic patient cohorts.

The risk of HCC appears to be greater with HCV GT-1b compared with HCV GT-2a/2c [31]. In contrast to hepatitis $B$ virus (HBV) infection, HCC in patients with hepatitis $\mathrm{C}$ occurs almost exclusively in those with cirrhosis, suggesting that cirrhosis is the major risk factor. There is also suggestive experimental evidence that $\mathrm{HCV}$ infection itself can promote development of HCC. In addition, obesity is an independent risk factor for HCC development in chronic hepatitis $\mathrm{C}$ patients [32]. HCV GT-3 is also associated with a significantly increased risk of developing cirrhosis and HCC compared with HCV GT-1 [33-36].
Recent study [37] demonstrated that patients with diabetes or HCV GT-3 infection were significantly more likely to develop HCC after sustained virologic response (SVR) in veterans with $\mathrm{HCV}$ infection in the USA.

\section{Survival}

Survival is decreased in patients with HCV, especially in those who have developed cirrhosis. Compared with uninfected patients, patients with chronic HCV infection are more likely to die at a younger age and, as expected, from liver-related causes [38, 39]. In the large prospective HALT-C trial, which included 1050 patients with advanced fibrosis or cirrhosis who were followed for a median of 5.7 years, 122 patients $(12 \%)$ died and an additional 74 patients ( $7 \%$ ) underwent liver transplantation [40]. In a series of 384 patients with compensated cirrhosis, the 3-, 5-, and 10-year survival rates were 96, 91, and $79 \%$, respectively [41]. Once decompensated cirrhosis occurred, the 5-year survival declined substantially to approximately $50 \%$. Survival may also be worse in patients who develop cryoglobulinemia. Causes of death among patients with HCV vary with the age group being examined. In a population study from Denmark, the primary cause of death among patients aged 20-39 years was unnatural (reported as death due to mental and behavioral disorders related to psychoactive substance use and death resulting from external causes). The 10-year risk of unnatural death in patients between the ages of 20 and 29 years was $13 \%$. In patients between the ages of 40 and 59 years, deaths were equally distributed among liver-related, non-liver-related, and unnatural causes. In patients 70 years of age or older, the most common causes of death were non-liver related. Patients with HCV were at increased risk of death compared with non-HCV-infected individuals at all ages, ranging from an 18-fold increase for 20-29-year-olds to a 1.6-fold increase for patients aged 70 years or greater [42]. Mortality in patients with $\mathrm{HCV}$ is not always related to liver disease. A population-based study from Australia found that most deaths in young patients with $\mathrm{HCV}$ were due to continued drug use rather than the infection [43].

\section{$H C V$ infection and extrahepatic manifestation}

Some patients with chronic HCV infection may suffer from extrahepatic illnesses, with a symptomatic spectrum varying from fatigue to permanent organ damage. These illnesses resolve following SVR by antiviral treatment [4]. Interferon-free treatment appears safe and effective in HCV patients with certain extrahepatic manifestations [44, 45]. 
Hepatitis $C$ virus genotype 3 infection and hepatic steatosis

Patients infected with HCV often have hepatic steatosis. Several studies reported that HCV GT-3 infection was associated with hepatic steatosis compared with HCV GT-1 infection [46-48]. HCV GT-3 is the most prevalent HCV GT in patients with chronic HCV infection in North and Central India, where HCV GT-3 is also associated with significant hepatic steatosis and fibrosis [49]. Among patients infected with HCV GT-3, SVR significantly reduced steatosis, but there was no change in steatosis among those without SVR [50]. Expression of steatosisassociated HCV GT-3 core protein produces intracellular lipid accumulation in primary and cultured hepatocytes [51], and polymorphisms in HCV GT-3 core protein could produce increased intracellular lipid levels [52]. These facts may indicate the direct cytopathic effect of $\mathrm{HCV}$ core protein.

\section{Chronic HCV infection and insulin resistanceldiabetes mellitus}

Several studies have shown a higher prevalence of $\mathrm{HCV}$ antibodies in patients with diabetes mellitus than in the general population $[53,54]$. HCV infection is associated with insulin resistance/diabetes mellitus in adult patients with cirrhosis undergoing assessment for liver transplantation [55]. Allison et al. [55] reported that the prevalence of diabetes mellitus was $50 \%$ in cirrhotic patients infected with $\mathrm{HCV}$, and it was $9 \%$ in those without HCV. Although there are several basic associations between $\mathrm{HCV}$ infection and insulin resistance/diabetes mellitus [56, 57], it might be difficult to cure insulin resistance/diabetes mellitus in patients with HCV and advanced liver fibrosis with interferon-free regimens.

\section{Chronic hepatitis $C$ virus infection in patients with normal versus high serum aminotransferase levels}

$\mathrm{HCV}$ infection with normal ALT is defined by detectable HCV RNA and a serum ALT concentration that is persistently within the normal range. Using this definition, approximately $25-40 \%$ of patients with chronic HCV infection have persistently normal serum ALT. It has been proposed that the upper limit of normal may be set too high because of unrecognized fatty liver disease among apparently healthy individuals who were included in the cohorts used to establish the normal range. This is supported by a study in which a decrease in ALT levels was noted in patients with "normal" ALT levels who achieved a SVR after undergoing treatment [58].
Many anti-HCV-positive patients with normal serum ALT concentrations have an abnormal liver biopsy, although the changes are usually mild. Patients with a persistently normal ALT are more likely to be female and generally have milder disease, a lower serum HCV RNA level, and a relatively favorable prognosis, although up to $10 \%$ of patients have bridging fibrosis, suggesting that the relatively favorable prognosis is not universal [59]. A significant proportion of patients $(20-30 \%)$ experience ALT flares that may be associated with enhanced disease progression [60].

\section{Predictive models for disease progression}

Many multivariate models that can help predict disease progression in individual patients have been developed. Baseline data collected as part of the HALT-C trial were used to develop predictive models for both clinical and histological outcomes. The 1050 patients in the HALT-C trial were previous nonresponders to standard interferon therapies who had advanced fibrosis on liver biopsy. Clinical outcomes were defined as an increase in ChildPugh score to seven or greater, variceal bleeding, ascites, spontaneous bacterial peritonitis, hepatic encephalopathy, and liver-related death. The histological outcome for the study was an increase in Ishak fibrosis score of two or more points (biopsies taken at 1.5 and/or 3.5 years after randomization).

Factors predictive of clinical outcomes on multivariable analysis were elevated aspartate aminotransferase (AST)/ ALT ratio, elevated total bilirubin, low albumin, low platelet count, and increasing Ishak fibrosis score. Factors predictive of histological progression were increasing body mass index, low platelet count, and hepatic steatosis [61]. In another study, clinical and laboratory variables among 247 patients with varying degrees of $\mathrm{HCV}$ histologic severity were analyzed. Death from liver failure, development of HCC, and liver transplantation were considered together in the statistical analysis. History of hepatic decompensation (defined as at least one episode of ascites, jaundice, hepatic encephalopathy, or gastrointestinal bleeding of variceal origin) and serum albumin concentration were independent predictors of the above outcomes. Patients without history of decompensation and serum albumin concentration greater than $4.1 \mathrm{mg} / \mathrm{dL}$ ( $41 \mathrm{~g} / \mathrm{L})$ had only a $3 \%$ chance of developing one of the endpoints within 5 years versus approximately $6 \%$ in patients with one of these factors and $40 \%$ in patients with both factors [62].

In a third study of 455 patients who were followed for a median of 4.7 years, the only independent predictors of progression on multivariable analysis were sporadic transmission, advanced fibrosis, and low albumin [63]. 
Spontaneous resolution of chronic hepatitis $C$

Spontaneous resolution of chronic hepatitis $\mathrm{C}$ is relatively rare and has been reported in only a few longitudinal or retrospective studies. Rates of $0.5 \%$ resolution per year per person have been observed [64]. However, HCV RNA can persist at very low levels in the serum, peripheral lymphoid cells, and brain for many years after apparent resolution of chronic hepatitis $\mathrm{C}$.

\section{Effect of antiviral therapy and natural history of $\mathrm{HCV}$ infection}

Recent data demonstrate that antiviral therapy, particularly among those achieving a SVR, is associated with long-term persistence of a SVR, improved fibrosis and inflammation scores, reduced incidence of HCC, and prolonged life expectancy [4]. This reduction in the rate of progression has also been demonstrated in patients with chronic hepatitis $\mathrm{C}$ and cirrhosis in some studies. The impact on slowing progression is greatest in patients with a SVR, less in relapsers, and equivocal in nonresponders [4]. With the most recent approval of direct-acting antivirals (DAAs), the rates of SVR and virological cure have greatly increased across all HCV GTs for both treatment-naïve and treatment-experienced patients [4].

\section{Antiviral therapy and effect on hepatic fibrosis and inflammation}

Most of the studies on the effect of treatment of fibrosis have been limited by a lack of long-term follow-up after treatment versus untreated patients. Ongoing cofactors such as alcohol and metabolic syndrome are likely to play a significant role. The majority of patients (57-94\%) demonstrate marked improvements in their necroinflammation and fibrosis scores following a SVR [65-68]. However, a small minority (1-14\%) of patients demonstrated fibrosis progression following a SVR [69]. Young age and platelet count at the SVR are predictive of fibrosis regression [70]. The HALT-C study showed that long-term therapy with peginterferon did not reduce the rate of disease progression in patients with chronic hepatitis $\mathrm{C}$ and advanced fibrosis, with or without cirrhosis, who did not have a response to initial treatment with peginterferon and ribavirin.

Patients with HCV cirrhosis who achieve a SVR have a reduction in their portal pressure measurements compared with nonresponders [71]. Although achieving a SVR prevents development of esophageal varices in the majority of patients with compensated HCV cirrhosis, a recent prospective study showed that, although the risk of developing varices post-SVR was vastly reduced, it was not eliminated, with a small number of patients developing small esophageal varices (2/57) [72].

A meta-analysis of data from 1013 patients from three large randomized trials demonstrated that peginterferon treatment reduced inflammation and fibrosis in patients with a SVR or who relapsed, but not in nonresponders. This improvement was more prominent with the use of peginterferon than with interferon [73]. Even in patients with advanced fibrosis or cirrhosis, inflammation and fibrosis are improved with interferon monotherapy, peginterferon monotherapy, or peginterferon plus ribavirin combination therapy [74]. Overall, studies of antiviral therapy with interferon monotherapy, peginterferon monotherapy, or peginterferon plus ribavirin combination therapy demonstrated improvement in inflammation and fibrosis in patients with a SVR, to a lesser extent in relapsers, and uncertain benefit in nonresponders.

Overall, progression of liver fibrosis to cirrhosis is rare but can occur despite a SVR. Based on a large pooled dataset from 3010 naïve patients, one study estimated the prevalence at $7 \%$ [75]. However, another study of 121 patients with pre- and posttreatment liver biopsies reported fibrosis progression in $12 \%$ of patients after ruling out de novo infections or existence of occult HCV via polymerase chain reaction (PCR) of liver tissue [76]. The presence of significant liver comorbidities or risk factors such as alcohol consumption or fatty liver disease are likely causes for many of the cases in which progression of liver diseases occurs post-SVR. In general, the combination of more than one liver disease, for example, hemochromatosis with alcohol consumption, or chronic viral hepatitis with alcoholic liver injury, can drive fibrosis progression in HCV patients [77].

\section{Antiviral therapy and effect on incidence of hepatocellular carcinoma}

Among those with chronic HCV infection without advanced fibrosis or cirrhosis, the incidence of HCC is decreased in patients with a SVR and probably also in relapsers when compared with nonresponders [78]. Several studies and a meta-analysis have concluded that eradication of HCV with antiviral therapy reduces the risk of HCC in patients with chronic hepatitis $\mathrm{C}$, independent of fibrosis stage $[79,80]$. However, a reduction in the risk of HCC does not necessarily indicate improvement in overall survival, and interferon is less effective in patients with cirrhosis. In addition, cirrhotic patients tend to be older, and liver-unrelated mortality may be significant and obscure any potential benefit of interferon therapy. A few studies have shown that, in patients with advanced fibrosis and/or 
cirrhosis who achieved a SVR, the age-adjusted hazard ratio for developing $\mathrm{HCC}$ and death is significantly reduced. The failure to achieve a SVR was associated with a higher risk of liver-related complications, HCC, and liver-related mortality compared with those who achieved a SVR [81]. However, several studies have demonstrated no beneficial effect of interferon therapy on the prognosis of cirrhotic patients. A recent meta-analysis that included 30 studies comprising 31,528 patients from 17 countries reported a $4.6 \%$ absolute reduction in developing HCC following a SVR [82]. Furthermore, in patients with advanced liver disease, achieving a SVR reduced the overall risk of developing HCC from 17.8 to $4.2 \%$, with a reduction in incidence from $3.3 \%$ per person-year to $1.05 \%$ (CI 0.7-1.5\%) per person-year. Prospective data extracted from the HALT-C cohort also suggested that, following a SVR, the incidence of HCC decreased from 8.8 to $1.1 \%$ over approximately 7 years of follow-up. A recently published meta-analysis demonstrated that antiviral treatment was associated with a reduced risk of HCC in patients who attained a SVR, compared with nonresponders; the best outcomes were observed in patients treated with ribavirin-based regimes [83]. The attainment of a SVR also demonstrated prevention of the development of esophageal varices [72, 84]. There have been case reports and long-term follow-up studies that have shown development of HCC in patients with advanced hepatic fibrosis after achievement of a SVR. These observations underscore the continued risk of $\mathrm{HCC}$ and the need for ongoing surveillance with imaging and alpha-fetoprotein (AFP) testing in patients with chronic hepatitis $\mathrm{C}$ and advanced hepatic fibrosis or cirrhosis, even after a SVR. A recent study tried to risk-stratify patients further by creating a scoring system based on age, platelets, AFP, and fibrosis score [85]. Patients were identified as low, medium, or high risk depending on their score. In the low-risk group, 9 out of 657 patients developed HCC over 9 years, equating to a $0.17 \%$ risk per annum, an incidence rate that is well below that where screening is deemed cost effective. If this score is validated, it may help identify which patients should be recommended for long-term HCC surveillance. Achievement of eradication of $\mathrm{HCV}$ was associated with a marked decrease of HCC [28].

\section{Antiviral therapy and effect on life expectancy}

It is expected that long-term durability of a SVR, improvement in fibrosis and inflammation, and a reduced incidence of HCC translate into prolonged life expectancy. Interferon treatment decreases the risk ratio for overall death and liver-related death, particularly in patients with a SVR, while the risk of liver-unrelated death remains unchanged [86, 87].

\section{\#1 Consensus statements and recommendations on natural history of $\mathrm{HCV}$ infection}

1. HCV can lead to persistent infection in a high proportion of infected individuals. (A1)

2. Chronic HCV infection is generally a slowly progressing disease characterized by persistent hepatic inflammation, leading to the development of cirrhosis in approximately $10-20 \%$ of patients over 20-30 years of HCV infection. However, the published data indicate varying progression rates to cirrhosis. (A1)

3. Once cirrhosis has developed, there is a $1-5 \%$ annual risk of $\mathrm{HCC}$ and a 3-6\% annual risk of hepatic decompensation. (A1)

4. Following an episode of decompensation, the risk of death in the following year is between 15 and $20 \%$. (A1)

5. Achievement of a SVR leads to improved mortality and reduced adverse outcomes, although fibrosis progression and de novo HCC still occur post-SVR in a small subset of patients. (A1)

6. With the availability of DAAs, the rates of SVR and virological cure have vastly increased across all HCV genotypes for treatment-naïve patients as well as for treatment-experienced patients, especially for patients with cirrhosis, where cure has been difficult and where side effects to interferon-based regimens were difficult to tolerate and often precipitated decompensation. (A1)

7. DAAs could have an impact on the complications of cirrhosis, but this feature needs to be further investigated. (C2)

\#\# Grading of evidence and recommendations are shown in Supplementary Table 1.

\section{Prevention of HCV infection in Asia}

The World Health Organization estimates that more than 185 million people worldwide might be infected with $\mathrm{HCV}$ [88]. These are crude estimates with significant differences in prevalence, from $2.0 \%$ in South East Asia to 3.7-3.8\% in East and Central Asia [89], and the highest of approximately $15 \%$ in Egypt [90]. The prevalence of hepatitis C infection varies significantly in different areas and different populations among or within countries, implying different routes of transmission and different strategies needed to prevent HCV transmission [91, 92].

Effective prevention of $\mathrm{HCV}$ can occur through the use of a prophylactic vaccine, but vaccine trials are still in early phases or progressing slowly [93]. Therefore, the current 
approach for the prevention of $\mathrm{HCV}$ infection is to reduce transmission by reducing the risk of exposure to the virus, potentially by treatment with newly developed DAAs. In addition to a universal prevention strategy to reduce transmission by blood transfusion and other unsafe medical procedures including unsafe injection, unsafe dental management, hemodialysis, acupuncture, catheters, and other medical equipment, specific risk populations should be identified to develop population-specific prevention strategies, such as for people who inject drugs (PWID) using contaminated injection equipment, people with skin or mucous membrane inoculation, or with exposure of broken skin to contaminated blood such as through use of intranasal drugs or cosmetic procedures [94]. Sexual transmission occurs particularly in the HIV coinfected population, but is at low or no risk in heterosexual couples. Meanwhile, male who have sex with male (MSM) were recently shown to be an at-risk population. Higher prevalence of $\mathrm{HCV}$ among HIV-positive than HIV-negative male was observed in the Asia-Pacific region [95]. The majority of acute hepatitis $\mathrm{C}$ in HIV-infected patients were MSM [96, 97]. Transmission from an infected mother to infant depends on the activity status of HIV coinfection during pregnancy.

Due to the few clinical manifestations of chronic $\mathrm{HCV}$ infection, screening is important based on the geographical region and risk population. It would be more helpful to identify HCV infection earlier than to reduce transmission and the infection pool by initiating treatment.

\section{Blood safety}

In 1992, the introduction of second-generation anti-HCV ELISA largely eliminated HCV transmission via donated blood by screening out infected donors. Third-generation anti-HCV enzyme immunoassay (EIA) further reduced the window period by at least 1 week. Nucleic acid testing (NAT) can further reduce the risk of $\mathrm{HCV}$ transmission to 0.1-2.33 per million donations by mini-pool or individual donation testing [4, 98, 99].

NAT was applied to donor HCV screening in Germany in 1997. In the Asia-Pacific region, NAT has been used for blood screening in Japan since 1999, Australia and Singapore since 2000, New Zealand since 2001, Hong Kong since 2002, South Korea since 2005, Thailand since 2006, Malaysia since 2007, Taiwan since 2008, and Mainland China since 2014 [100].

$\mathrm{HCV}$ antigen assays, another method of detection of active HCV infection, have been commercially available for a couple of years and can detect both free antigen and antibody-combined antigen. A few studies have shown that they can shorten the window period. Therefore, this was applied in blood testing to enhance the overall effectiveness of serological HCV screening in some countries [101103]. However, the Global Database on Blood Safety shows that testing with anti-HCV ELISA is insufficient, particularly in countries with a low human development index-only $51.3 \%$ of units of blood are tested for $\mathrm{HCV}$ [104]. Blood donations are still not routinely tested for infectious markers including HCV in 39 countries. Overall, $47 \%$ of donations are tested in laboratories without quality assurance; most were in Asia [105]. Even the testing technologies varied by country, from all technologies in Egypt to a few blood centers in India, with the number of voluntary unpaid blood donations increasing from 3.6 million in 2007 to 4.6 million in 2008 .

\section{\#2 Consensus statements and recommendations on blood safety}

1. All countries must establish a national system for blood donor selection for the donation of blood or blood components. (A1)

2. Regular audit procedures should be implemented to ensure compliance at blood-testing facilities. (B2)

3. Anti-HCV antibody tests must be quality-assured with third-generation EIA or chemiluminescence immunoassay (CIA). (A1)

4. Application of HCV antigen assays and/or nucleic acid testing for the universal screening of blood products should be country specific based on availability and cost. (B2)

\section{Prevention in healthcare settings}

HCV infections are more likely to occur in healthcare settings with low compliance with universal precautions, associated with social imbalance, inequity of income, and inequity of health, particularly in low- and middle-income countries. The risks of HCV infection in healthcare settings include unsafe injection, dental management, medical procedures, and hemodialysis, and sometimes acupuncture in certain countries or areas.

In a meta-analysis, unsafe injection practices were found to be widespread in the developing world, accounting for more than $50 \%$ of infections. It was estimated that each person in the developing world receives 1.5 injections per year on an average. However, at least $50 \%$ of injections were unsafe in 14 of 19 
countries [106]. Moreover, $82 \%$ of administered injections in Asia were considered unnecessary [107]. Reuse of needles and reuse of syringes remain a common practice in Bangladesh and Pakistan [108, 109]. Unsafe injections have been estimated to transmit 2.3-4.7 million $\mathrm{HCV}$ infections every year [110].

It was estimated that $40 \%$ of new HCV infections are associated with unsafe injections globally [111]. The average incidence of anti-HCV seroconversion after accidental percutaneous exposure from HCV-positive source is $1.8 \%$ [112]. Unfortunately, unsafe injections remain a problem in developing areas, where $75 \%$ of unsafe injections are still conducted with insufficiently sterilized equipment [111]. Other risks of HCV infection involve acupuncture and needle-stick injury, which account for up to $7 \%$ of HCV infections $[4,113]$.

Medical procedures associated with HCV infection are inevitable due to low compliance with universal precautions [104] including surgical procedures [114], gastrointestinal endoscopy [115], radiopharmaceuticals [116], and oncology procedures. Low compliance with universal precautions also contributed to hemodialysisassociated HCV infection [117]. Mishandling of parenteral medication vials is a major risk for $\mathrm{HCV}$ infection outbreaks in dialysis units. In Egypt, the HCV infection rate was as high as $50-90 \%$ among dialysis patients [118]. The Centers for Disease Control and Prevention (CDC) recommends that all single-use injectable medications and solutions be dedicated for use on a single patient. Medications packaged as multidose should be assigned to a single patient whenever possible [119].

The occurrence of HCV infection in healthcare settings varies depending upon the frequency of injections, medical procedures, etc. and the level of compliance with universal precautions. High frequency of injections and low compliance with universal precautions is strongly associated with a high prevalence of $\mathrm{HCV}$ in the general population. Compliance with universal precautions varies in the AsiaPacific region; it is lowest in Turkey at $33.6 \%$ [120], $40 \%$ in India [121], and $64.7 \%$ in China [122]. The knowledge of universal precautions was inadequate in some countries in Asia [121-124]. The factors influencing compliance were irregular supply of materials, lack of other high-level disinfection equipment, and lack of training [121, 123125].

Body piercing, tattooing, and cosmetology are also associated with potential HCV infection [126, 127]. Tattoo-associated $\mathrm{HCV}$ infection is one of the greatest risks in some Asian countries such as Bangladesh, India, and Japan [1]. These data show that non-healthcare transmission routes should also be noted.

\section{\#3 Consensus statements and recommendations on prevention in healthcare settings}

1. In healthcare settings, universal precautions should be followed for healthcare and cosmetology workers and strictly carried out. (A1)

2. Regular audit should be implemented for hand hygiene, safe handling and disposal of sharp objects and waste, and safe cleaning of equipment. (B2)

3. Unnecessary injections should be avoided. (B2)

\section{Prevention for persons who inject drugs (PWID)}

PWID are important sources of $\mathrm{HCV}$ infection, particularly in middle- and high-income countries. Most HCV prevalence studies are based on anti-HCV because PCR-based tests are rarely used in epidemiological studies. The estimated HCV prevalence rates varied among PWID in the Asia-Pacific region. Recently, a systematic review showed that midpoint reports ranged from $36.0 \%$ in Afghanistan to $89.8 \%$ in Thailand. China has the largest estimated population of PWID and had midpoint estimates of anti-HCV prevalence amongst PWID of $67.0 \%$ [128]. Due to the common transmission route of sharing contaminated injecting equipment, the prevention strategy for $\mathrm{HCV}$ infection should be the same as that for prevention of HIV infection [88].

"Needle and syringe" programs, including other drugusing paraphernalia, should be recommended, and "condom" programs for people who inject drugs and their sexual partners are advisable. In addition to HIV infection prevention, HCV transmission-specific strategies should be advocated. Those strategies include implementing sterile needle and syringe programs that provide low-dead-space syringes for distribution to people who inject drugs, offering peer interventions to people who inject drugs to reduce the incidence of viral hepatitis, offering opioid substitution therapy to treat opioid dependence, reducing HCV risk behavior and transmission through injecting drug use, and increasing adherence to HCV treatment [88], although a meta-analysis showed that there was insufficient evidence that interventions with needle and syringe programs were effective [129].

Another systematic review showed no clear association of $\mathrm{HCV}$ prevalence with duration of injection use or age of users [130]. Unfortunately, many countries do not provide sterile needle and syringe programs, and the same countries do not provide sufficient coverage even if they do have those programs. It is estimated that only 22 syringes are provided per year per person who injects drugs. In the Asia-Pacific region, Australia had by far the greatest rate of needle-syringe distribution at 202 needle-syringes per 
PWID per year; however, the rate of needle-syringe distribution is only 0.5 needle-syringes per PWID per year in the Middle East [131].

In addition to injected drugs, a systematic review suggested that noninjection drug use is also associated with a higher risk of HCV infection, such as sharing of inhalation equipment for cocaine [132].

\section{\#4 Consensus statements and recommendations on HCV prevention for persons who inject drugs (PWID)}

1. Because transmission of $\mathrm{HCV}$ via injecting drug users (IDUs) is an increasing trend in the AsiaPacific region, effective strategies to reduce $\mathrm{HCV}$ transmission in this group should be explored. (B2)

2. Harm reduction including "sterile needle and syringe programs" should have increased coverage. (B2)

\section{Prevention of infection via sexual transmission}

Based on a cross-sectional study of sexual transmission of $\mathrm{HCV}$ among monogamous heterosexual couples, the maximum incidence rate of $\mathrm{HCV}$ transmission by sex was as low as $0.07 \%$ per year or approximately one per 190,000 sexual contacts. No specific sexual practices were related to HCV positivity among couples [133]. However, another Asian study showed that the seroprevalence rates of anti-HCV were $5.5 \%$ in HIV-positive MSM and $0.4 \%$ in HIV-negative MSM [134]. This result is similar to that of a community survey conducted in London, UK that showed that the seroprevalence of anti-HCV was more common in the HIV-infected population $(7.7 \%$ ) than in those without HIV infection $(1.2 \%)$ [135]. Therefore, the risk of sexual transmission is strongly associated with preexisting HIV infection and unsafe sex [136], and there is low or no risk of sexual transmission of HCV among HIV-uninfected heterosexual couples.

\section{\#5 Consensus statements and recommendations on prevention of sexual transmission}

1. There is low or no risk of sexual transmission of HCV among HIV-uninfected heterosexual couples. (A2)

2. It is recommended that correct and consistent condom use be applied in MSM with HIV infection. (B2)

\section{Mother-to-infant transmission}

Mother-to-infant transmission (also called vertical transmission) is significantly affected by coinfection with HIV. The transmission rate varied from 4 to $8 \%$ among mothers without HIV coinfection; however, it increased to $17-25 \%$ among mothers coinfected with HIV [137-140]. Breastfeeding was not significantly associated with transmission [141], and cesarean section did not decrease perinatal HCV transmission from mothers to infants [140]. Therefore, no specific prevention method can be recommended for this population. The safety and potential efficacy of reducing mother-toinfant transmission by recently developed DAAs or those under development, particularly in HIV coinfection, require more research.

\section{\#6 Consensus statements and recommendations} on mother-to-infant transmission

1. No specific precaution is needed for breastfeeding to prevent vertical transmission. (B2)

\section{Reinfection in PWID}

HCV reinfection occurs commonly in PWID. PWID with previous infection with $\mathrm{HCV}$ clearance are half as likely to be reinfected compared with those who had not been infected previously. However, other studies suggested that previous spontaneous clearance of $\mathrm{HCV}$ infection might not reduce the risk of new infection [142]. Ongoing highrisk behaviors among PWID can lead to repeated exposure to $\mathrm{HCV}$, resulting in reinfection [143]. Although reinfection is common, it does not always lead to persistent infection. Spontaneous clearance of HCV reinfection has also been frequently reported with a different HCV GT from that of the initial infection [142]. Reinfection rates for PWID receiving opioid substitution therapy (OST) are the most well studied. The rate of reinfection in this population is low [144].

In essence, $\mathrm{HCV}$ reinfection after spontaneous or treatment-induced clearance can occur. However, the rate of $\mathrm{HCV}$ reinfection might be as low as $0-5$ cases per 100 person-years, even among persons who continue injected drug use during and after treatment [143, 145, 146]. Due to the low reinfection rate and potential clearance after reinfection, antiviral treatment should not be withheld for these populations. 


\section{\#7 Consensus statements and recommendations on prevention of reinfection in PWID}

In high-risk HCV-reinfection populations (PWID), frequent testing is recommended. Education and counseling about the risk of reinfection are advised for this population. (B1)

\section{Reinfection following liver transplantation}

Reinfection following liver transplantation has been observed, and it leads to liver disease in approximately $30 \%$ of patients. However, newly developed DAAs make it easy to achieve a SVR both among compensated liver transplant recipients with no fibrosis or mild fibrosis [147, 148] and before liver transplantation [149].

\section{\#8 Consensus statements and recommendations on prevention of reinfection in liver transplant recipients}

Liver transplant recipients with HCV reinfection should be treated with highly efficacious DAAs. (B1)

\section{HCV laboratory testing before and after SVR}

\section{Serologic assays}

Exposure to $\mathrm{HCV}$ is determined by testing for anti-HCV antibodies using an approved enzyme (EIA) or chemiluminescent immunoassay (CIA). The presence of anti-HCV antibodies indicates a current or previously resolved HCV infection. The absence of anti-HCV antibodies usually shows that the patient has not been infected. However, anti$\mathrm{HCV}$ antibodies might not be detectable in the first few weeks after the initial infection (window period) in immunosuppressed patients, or in patients who resolve their infection many years later $[150,151]$.

Several countries in the Asia-Pacific region have developed their own individual testing algorithms for antiHCV antibody testing. A high signal-to-cutoff ratio for a sample in a specific EIA is highly predictive of an authentic anti-HCV antibody reactive result. The recombinant immunoblot $\mathrm{HCV}$ assays recommended for supplemental testing are no longer available. Molecular testing for $\mathrm{HCV}$ RNA is currently the only supplemental testing [4, 152].

Recently, rapid assays for detecting HCV antibodies in fingerstick capillary blood and venipuncture whole blood were shown to provide high sensitivity and specificity of $>98 \%$ [153]. Given their very high accuracy, convenience, and quick turnaround time, rapid diagnosis tests (RDT) and point-of-care tests (POCT) may be useful in nontraditional settings such as emergency departments, outreach clinics, and community-based organizations.

The currently available HCV core antigen quantitative assay has a sensitivity of $90 \%$ for samples with HCV RNA $>10,000 \mathrm{IU} / \mathrm{mL}$ and a specificity of near $100 \%$ across HCV GT-1-6 [154]. There is good correlation between $\mathrm{HCV}$ core antigen and HCV RNA levels. However, it is probably not suitable for on-treatment monitoring due to its limited sensitivity. The major role these assays might play is in the identification of blood donors in the seroconversion window.

\section{\#9 Consensus statements and recommendations on anti-HCV testing}

1. Anti-HCV antibody testing should be performed using approved anti-HCV third- or fourth-generation EIA or CIA. (A1)

2. Samples negative in an approved EIA/CIA can be reported as anti-HCV negative. However, it should be noted that individuals on hemodialysis or coinfected with HIV might be HCV RNA positive but anti-HCV negative. (A1)

3. Samples reactive in an approved single EIA can be reported as anti-HCV positive provided the signalto-cutoff ratio is sufficiently high to be predictive of a true positive.* (B1)

4. Noninstrumented point-of-care tests (POCT) with rapid anti-HCV testing could serve as first-line screening for hepatitis C (B2).

*The ratio is calculated by dividing the optical density (OD) value of the test sample by the OD of the assay cutoff. An example of the calculation of the ratio: Sample OD $=2.991$, cutoff $\mathrm{OD}=0.377$, therefore S/CO ratio $=7.934$. For most standard EIAs (i.e., those not using chemiluminescence), $\mathrm{S} / \mathrm{CO}$ ratio greater than 3-4 should be indicative of the presence of true anti$\mathrm{HCV}$ antibodies.

\section{Molecular assays}

\section{Nucleic acid testing (NAT) for HCV RNA detection}

NATs remain the gold standard for diagnosing HCV viremia, determining acute or chronic infection, and monitoring/assessing virologic responses to antiviral therapy. HCV RNA testing should be strongly considered in patients at high risk of infection but who might be anti- 
$\mathrm{HCV}$ negative because they are in the early phase of acute $\mathrm{HCV}$ infection or immunosuppression.

The assays used for qualitative HCV RNA testing include endpoint PCR and transcription-mediated amplification (TMA), which have detection limits of 50 and $10 \mathrm{IU} / \mathrm{mL}$, respectively. Although negative TMA results are more predictive of a SVR, a single positive TMA result should be interpreted with caution because patients with positive TMA results may achieve a SVR [155]. Recently, with the introduction of more sensitive quantitative realtime PCR assays, qualitative NATs may be only useful in mass screening of blood donors [156].

HCV viral loads, although not associated with disease activity or progression to chronicity, have been associated with disease progression [157], development of HCC [158], and the treatment outcome of anti-HCV therapy with both interferon-based regimens [159, 160] and new, powerful DAA interferon-free regimens [161]. Monitoring of viral loads during therapy has proven to be useful in individualized HCV therapy. Futility rules and responseguided therapy (RGT) based on in-treatment virologic responses at treatment weeks $4,8,12$, and 24 could provide information for optimal treatment durations to avoid unnecessary therapy, maximize cost-effectiveness, and minimize adverse events with interferon-based therapy [162-165].

Commercial signal amplification (e.g., branched-DNA assay) and target amplification assays (e.g., real-time PCR assays) are available for quantification of HCV RNA. Inhouse testing with traditional endpoint PCR for viral loads, which is used widely across the Asia-Pacific region, is not encouraged due to its limited dynamic range compared with commercial, sensitive PCR assays [166]. Such assays should be calibrated to the World Health Organization (WHO) International Standard [167].

With recent advances in RGT strategies and new treatment regimens with DAAs, only assays with a lower limit of quantification of $\leq 25 \mathrm{IU} / \mathrm{mL}$ and a lower limit of detection of $15 \mathrm{IU} / \mathrm{mL}$ are recommended. The presence of detectable but not quantifiable HCV RNA is clinically important because this condition reflects true viremia [168]. Therefore, several real-time PCR assays, which have a broad dynamic range of quantification and are sensitive, specific, precise, and reproducible, are preferred [169172]. In contrast, the bDNA assay, with its low sensitivity, has limited applicability in monitoring treatment.

The traditional primary endpoint of assessing anti-HCV therapy is SVR24 (HCV RNA $<50$ IU/mL 24 weeks after end of treatment), which indicates that HCV RNA remains negative during long-term follow-up [173]. Recent studies demonstrated that SVR12 (HCV RNA $<25 \mathrm{IU} / \mathrm{mL}$ 12 weeks after end of treatment) had positive predictive values (PPV) of $>98 \%$ for SVR24, regardless of whether therapy was interferon based or DAA interferon free [174, 175]. SVR12 is currently widely used as the primary endpoint of clinical trials and regulatory approval for DAA-containing regimens. SVR12 was suitable for predicting persistent virologic response in almost all cases. In certain DAA-including regimens, SVR12 could not always predict persistent virologic response [176]. Further study of the difference between SVR12 and SVR24 will be needed in interferon-free regimens.

\section{\#10 Consensus statements and recommendations on HCV RNA testing}

1. For all samples positive for anti-HCV, HCV RNA should be determined by sensitive nucleic acid testing (NAT). (A1)

2. HCV RNA quantitation should be reported in IU/ $\mathrm{mL}$ (optionally including copies/mL). DAA-containing regimens should use assays with a lower limit of quantification of $\leq 25 \mathrm{IU} / \mathrm{mL}$ and a lower limit of detection of $\leq 15 \mathrm{IU} / \mathrm{mL}$. (B1)

3. Monitoring of $\mathrm{HCV}$ loads during treatment is important for response-guided therapy to determine futility, treatment protocol, and duration. (A1)

\section{HCV genotyping}

HCV genotyping is helpful in epidemiological studies and necessary for the clinical application of personalized therapy for chronic hepatitis C [177]. Currently, HCV has been classified into seven major GTs, which can be further divided into subtypes [178]. HCV GT-1, GT-2, and GT-3 are widely distributed in the Asia-Pacific region [179], whereas HCV GT-4 and GT-6 are mainly restricted to the Middle East and South East Asia, respectively, and are increasing in prevalence among IDUs [180]. RGT with interferon (IFN)-based therapy is HCV GT specific, and the currently available DAAs are GT and/or subtype specific.

Several methods targeting different regions [5'-untranslated region (UTR), core, NS5A, and NS5B] for $\mathrm{HCV}$ genotyping vary from country to country, potentially depending on approval by the relevant health authorities and/or available funding. Methods include direct sequencing, reverse-phase hybridization (e.g., line probe assay), type-specific PCR, restriction fragment length polymorphism analysis after PCR amplification, melting curve analysis after real-time PCR amplification, detection of HCV GT-specific antibodies, and restriction fragment mass polymorphism analysis. Genotyping methods with accurate determination of HCV GT-1 to GT-6 and 
distinction of HCV GT-1a from GT-1b are required for certain DAA-containing therapies [177].

\section{\#11 Consensus statements and recommendations on HCV genotyping}

HCV GT-1a/GT-1b testing is important for assessing treatment regimens and duration and the efficacy of antiviral therapy. (A1)

\section{Detection of HCV resistance-associated variants (RAVs)}

RAVs are naturally occurring HCV quasispecies in the viral life cycle whose frequency mainly depends on their replicational fitness. RAVs may be associated with inferior treatment efficacy, such as the resistance of HCV GT1a with Q80K mutation to simeprevir, a nonstructural protein 3/4A (NS3/4) protease inhibitor, plus peginterferon/ribavirin [181], and HCV GT-1b with NS5A-L31F/ $\mathrm{I} / \mathrm{M} / \mathrm{V}$ and/or NS5A-Y93H mutation resistance to the daclatasvir/asunaprevir all-oral regimen [182]. Excluding patients with preexisting RAVs could enhance treatment efficacy [183].

\section{\#12 Consensus statements and recommendations on HCV RAV detection}

Identification of baseline resistance-associated variants is helpful in certain DAA-containing regimens. (B2)

\section{Host genetic testing}

Host single-nucleotide polymorphisms (SNPs) near the interleukin-28B (IL28B, IFN-lambda 3) gene are associated with spontaneous and peginterferon/ribavirin treatment-induced viral clearance in HCV GT-1/GT-4 patients [184, 185] but have a limited role in HCV-2/3 patients [186]. Combined with baseline viral loads, viral kinetics, and previous treatment responses [177], the IL28B genotype could provide important information for decision-making in clinical practice, including: (1) identification of HCV GT-1 treatment-naïve patients who are eligible for 24-week peginterferon/ribavirin (IL28B favorable genotype with baseline viral loads $<400,000 \mathrm{IU} / \mathrm{mL}$ ) [160], (2) early identification of HCV GT-1 nonresponders (IL28B unfavorable genotype with
HCV RNA >1000 IU/mL at treatment week 4) [165], and (3) exclusion of retreatment with peginterferon/ribavirin for treatment-experienced HCV GT-1 patients who carry the IL28B unfavorable genotype [187].

\section{\#13 Consensus statements and recommendations on host IL28B genotyping}

In interferon-based treatment, IL28B genotyping could help in determining the treatment strategy. (A1)

\section{Assessment of liver fibrosis}

Acute assessment of liver fibrosis is of clinical importance in decision-making, especially in the era of DAA and IFN-free regimens. Patients with cirrhosis with or without other unfavorable factors, such as HCV GT-1a, HCV GT-3, and prior null responses, require intensified treatment [188-191]. Although liver biopsy remains the gold standard to assess liver fibrosis, alternative noninvasive approaches for liver fibrosis have assumed great importance.

Approaches include the following [192-194]:

- Noninvasive imaging (e.g., transient elastography and magnetic resonance elastography/spectroscopy).

- Noninvasive blood marker panels [e.g., aspartate aminotransferase-platelet ratio index (APRI), fibrosis4 (FIB-4), FibroTest, FIBROSpect II, Hepascore, FibroMeter, and FibroFast]. These tests can provide areas under the curve of $>0.7$ for identifying clinically significant fibrosis and $>0.8$ for identifying cirrhosis [195].

Although noninvasive markers and transient elastography are only useful for identifying those patients with no fibrosis or with advanced fibrosis, a stepwise algorithm incorporating noninvasive markers and/or transient elastography may enhance the accuracy of diagnosis and significantly reduce the number of liver biopsies [196, 197]. However, application of the algorithm in clinical practice remains to be validated. Furthermore, accumulating data provide evidence that noninvasive methods for liver fibrosis can be applied at a single point or repeatedly to provide prognostically meaningful distinctions in predicting clinical outcomes, with or without antiviral therapy, in chronic hepatitis C patients [198-200]. A recent study demonstrated that the 3-year evolution of the results of serial noninvasive assessment of hepatic fibrosis strongly predicts the long-term outcome in chronic hepatitis $\mathrm{C}$ patients [201]. 


\section{\#14 Consensus statements and recommendations on noninvasive assessment of fibrosis}

Noninvasive methods for assessing liver fibrosis are useful for identifying patients with no/minimal fibrosis or advanced fibrosis and can provide prognostically meaningful distinctions in predicting clinical outcomes in chronic hepatitis $\mathrm{C}$ patients before and after successful treatment. A stepwise algorithm incorporating the results of noninvasive methods may enhance the accuracy of diagnosis. Liver biopsies are not always recommended for the diagnosis of hepatitis $\mathrm{C}$ or the decision for the treatment of hepatitis C. (B1)

\section{Laboratory testing after $\mathrm{HCV}$ cure}

Long-term complications of chronic hepatitis $\mathrm{C}$, including HCC and decompensation, and all-cause mortality are largely reduced after achieving a SVR [202-205]. Nevertheless, SVR patients remain at risk of HCC development, especially those with old age, high baseline gamma-glutamyltransferase levels, advanced liver fibrosis or comorbidity such as diabetes [206-208]. High APRI 6 months after the end of treatment [209] and high posttreatment ALT or AFP levels [210] were independent factors significantly associated with HCC development. These data indicate that regular monitoring for HCC screening and good control of comorbidities after achieving a SVR are mandatory for $\mathrm{HCV}$ patients. Older age, male gender, advanced fibrosis, severe steatosis, lower serum albumin levels, non-SVR, and higher post-interferon-treatment ALT or AFP levels are identified as independent factors significantly associated with HCC development [210]. Occurrence of $\mathrm{HCC}$ is not a rare event during and after antiviral treatment in older HCV patients [211] or HCV patients with advanced fibrosis [210]. Further studies will be needed regarding this point after interferon-free treatment [212-216].

\section{\#15 Consensus statements and recommendations on laboratory testing after $\mathrm{HCV}$ cure}

1. Regular HCC screening after achieving a SVR is mandatory for $\mathrm{HCV}$ patients at high risk such as patients with advanced fibrosis, older patients, or male patients. (A1)

2. Comorbidities should be evaluated and well controlled to reduce their impact on the disease progression of chronic hepatitis $\mathrm{C}$ (B1).

\section{Compliance with ethical standards}

All procedures followed were in accordance with the ethical standards of the responsible committee on human experimentation (institutional and national) and with the Declaration of Helsinki 1975, as revised in 2008 (5). Informed consent was obtained from all patients included in the study. This article does not contain any studies with animal subjects.

Conflict of interest Alaaeldin Ibrahim, Cosmas Rinaldi Adithya Lesmana, Mamun Al-Mahtab, George K. K. Lau, Barjesh C. Sharma, Jose Sollano, Manoj Kumar, Ankur Jindal, A. Kadir Dokmeci, Geofferey W. McCaughan, Darrell H. G. Crawford, Jafri Wasim, and Shiv Kumar Sarin declare that they have no conflict of interest. Masao Omata received fees for being a speaker, consultant, and advisory board member for Bayer Co., Boehringer Ingelheim, Bristol-Myers Squibb, Otsuka, Astellas, Gilead Sciences, Chugai, Mitsubishi Tanabe, Kyorin, Merck Sharp \& Dohme, Dainippon Sumitomo, Vertex Pharmaceuticals, Takeda, and Zeria. Tatsuo Kanda received lecture fees from Chugai Pharmaceutical, MSD, Tanabe-Mitsubishi, DaiichiSankyo, Bristol-Myers Squibb, Gilead Sciences, and AbbVie and a research grant from Chugai and MSD. Lai Wei has research grants from BMS and Roche and received consulting fees from Abbott, AbbVie, BMS, Gilead, and Novartis. Ming-Lung Yu is a consultant and advisory board member and has grant support from AbbVie, BMS, Gilead, Roche, MSD, and Abbott. Wang-Long Chuang received speaker fees from Gilead, BMS, MSD, Roche, and Novartis and is a member of the following advisory boards: Gilead, AbbVie, and Roche. Saeed S. Hamid has conference travel support from Gilead. Jia-Horng Kao has served as a consultant for AbbVie, BristolMyers Squibb, Gilead Sciences, and Roche and has also served on speakers' bureaus for Roche, Bristol-Myers Squibb, Gilead Sciences, and Novartis. Osamu Yokosuka has research grants from Chugai Pharmaceutical, Bayer, MSD, Daiichi-Sankyo, Tanabe-Mitsubishi, and Bristol-Myers Squibb and received speaking fees from Merck Sharp and Dohme, Kowa Souku, Sysmex, Chugai Pharmaceutical Co., GlaxoSmithKline, Bristol-Myers Squibb, Ajinomoto-Seiyaku, Bayer, Abbott, Given Imaging, Mitsubishi Tanabe Pharm, Taiho Yakuhin, Dainippon Sumitomo Pharm, and Igaku-Seibutsugaku Institute.

Open Access This article is distributed under the terms of the Creative Commons Attribution 4.0 International License (http://crea tivecommons.org/licenses/by/4.0/), which permits unrestricted use, distribution, and reproduction in any medium, provided you give appropriate credit to the original author(s) and the source, provide a link to the Creative Commons license, and indicate if changes were made.

\section{References}

1. Omata M, Kanda T, Yokosuka O, Crawford D, Al-Mahtab M, Wei $\mathrm{L}$, et al. Features of hepatitis $\mathrm{C}$ virus infection, current therapies and ongoing clinical trials in ten Asian Pacific countries. Hepatol Int 2015;9:486-507

2. Zheng X, Ding W, Li G, Wu Y, Wu D, Zhu H, He J, Wang B, Zhao L, Zhu F, Lv H. Seroprevalence of transfusion-transmissible infectious agents among volunteer blood donors between 2006 and 2012 in Zhejiang, China. Blood Transfus 2015;13:401-410

3. Song Y, Bian Y, Petzold M, Ung CO. Prevalence and trend of major transfusion-transmissible infections among blood donors in Western China, 2005 through 2010. PLoS One 2014;9:e94528 
4. Omata M, Kanda T, Yu ML, Yokosuka O, Lim SG, Jafri W, Tateishi R, Hamid SS, Chuang WL, Chutaputti A, Wei L, Sollano J, Sarin SK, Kao JH, McCaughan GW. APASL consensus statements and management algorithms for hepatitis $\mathrm{C}$ virus infection. Hepatol Int 2012;6:409-435

5. Asian Pacific Association for the Study of the Liver (APASL) Hepatitis C Working Party, McCaughan GW, Omata M, Amarapurkar D, Bowden S, Chow WC, Chutaputti A, Dore G, Gane E, Guan R, Hamid SS, Hardikar W, Hui CK, Jafri W, Jia JD, Lai MY, Wei L, Leung N, Piratvisuth T, Sarin S, Sollano J, Tateishi R. Asian Pacific Association for the Study of the Liver consensus statements on the diagnosis, management and treatment of hepatitis C virus infection. J Gastroenterol Hepatol 2007;22:615-633

6. Ward JW. The hidden epidemic of hepatitis $\mathrm{C}$ virus infection in the United States: occult transmission and burden of disease. Top Antivir Med 2013;21:15-19

7. van de Laar TJ, Matthews GV, Prins M, Danta M. Acute hepatitis $\mathrm{C}$ in HIV infected men who have sex with men: an emerging sexually transmitted infection. AIDS 2010;24:1799-1812

8. Kanda T, Yokosuka O, Imazeki F, Saisho H. Acute hepatitis C virus infection, 1986-2001: a rare cause of fulminant hepatitis in Chiba, Japan. Hepatogastroenterology 2004;51:556-558

9. Thimme R, et al. Determinants of viral clearance and persistence during acute hepatitis $\mathrm{C}$ virus infection. J Exp Med 2001;194(10):1395-1406

10. Loomba R, Rivera MM, McBurney R, Park Y, Haynes-Williams V, Rehermann B, Alter HJ, Herrine SK, Liang TJ, Hoofnagle $\mathrm{JH}$, Heller T. The natural history of acute hepatitis C: clinical presentation, laboratory findings and treatment outcomes. Aliment Pharmacol Ther 2011;33(5):559-565

11. Farci P, Shimoda A, Coiana A, et al. The outcome of acute hepatitis $\mathrm{C}$ predicted by the evolution of the viral quasispecies. Science 2000; 288:339-344

12. Grebely J, Page K, Sacks-Davis R, et al. The effects of female sex, viral genotype, and IL28B genotype on spontaneous clearance of acute hepatitis $\mathrm{C}$ virus infection. Hepatology 2014;59:109-120

13. Amin J, Law MG, Micallef J, Jauncey M, Van Beek I, Kaldor JM, Dore GJ. Potential biases in estimates of hepatitis C RNA clearance in newly acquired hepatitis $\mathrm{C}$ infection among a cohort of injecting drug users. Epidemiol Infect 2007;135(1):144-150

14. Thomas DL, Thio CL, Martin MP, Qi Y, Ge D, O'Huigin C, Kidd J, Kidd K, Khakoo SI, Alexander G, Goedert JJ, Kirk GD, Donfield SM, Rosen HR, Tobler LH, Busch MP, McHutchison JG, Goldstein DB, Carrington M. Genetic variation in IL28B and spontaneous clearance of hepatitis $\mathrm{C}$ virus. Nature 2009;461:798-801

15. Santantonio T, Fasano M, Sagnelli E, Tundo P, Babudieri S, Fabris P, Toti M, Di Perri G, Marino N, Pizzigallo E, Angarano G; Acute Hepatitis C Study Group. Acute hepatitis C: a 24 -week course of pegylated interferon $\alpha$-2b versus a 12-week course of pegylated interferon $\alpha-2 b$ alone or with ribavirin. Hepatology 2014;59:2101-2109

16. Sagnelli E, Pisaturo M, Stanzione M, et al. Clinical presentation, outcome, and response to therapy among patients with acute exacerbation of chronic hepatitis C. Clin Gastroenterol Hepatol 2013;11:1174-1180

17. Kobayashi M, Tanaka E, Sodeyama T, Urushihara A, Matsumoto A, Kiyosawa K. The natural course of chronic hepatitis C: a comparison between patients with genotypes 1 and 2 hepatitis C viruses. Hepatology 1996;23:695-699

18. Kenny-Walsh E. Clinical outcomes after hepatitis C infection from contaminated anti-D immune globulin. Irish Hepatology Research Group. N Engl J Med 1999;340:1228-1233
19. Missiha SB, Ostrowski M, Heathcote EJ. Disease progression in chronic hepatitis $\mathrm{C}$ : modifiable and nonmodifiable factors. Gastroenterology 2008;134(6):1699-1714

20. Urabe Y, Ochi H, Kato N, Kumar V, Takahashi A, Muroyama R, Hosono N, Otsuka M, Tateishi R, Lo PH, Tanikawa C, Omata M, Koike K, Miki D, Abe H, Kamatani N, Toyota J, Kumada H, Kubo M, Chayama K, Nakamura Y, Matsuda K. A genomewide association study of $\mathrm{HCV}$-induced liver cirrhosis in the Japanese population identifies novel susceptibility loci at the MHC region. J Hepatol 2013;58:875-882

21. Patin E, Kutalik Z, Guergnon J, Bibert S, Nalpas B, Jouanguy E, Munteanu M, Bousquet L, Argiro L, Halfon P, Boland A, Müllhaupt B, Semela D, Dufour JF, Heim MH, Moradpour D, Cerny A, Malinverni R, Hirsch H, Martinetti G, Suppiah V, Stewart G, Booth DR, George J, Casanova JL, Bréchot C, Rice CM, Talal AH, Jacobson IM, Bourlière M, Theodorou I, Poynard T, Negro F, Pol S, Bochud PY, Abel L; Swiss Hepatitis C Cohort Study Group; International Hepatitis C Genetics Consortium; French ANRS HC EP 26 Genoscan Study Group. Genome-wide association study identifies variants associated with progression of liver fibrosis from HCV infection. Gastroenterology 2012;143:1244-1252

22. Graham CS, Baden LR, Yu E, Mrus JM, Carnie J, Heeren T, Koziel MJ. Influence of human immunodeficiency virus infection on the course of hepatitis $\mathrm{C}$ virus infection: a meta-analysis. Clin Infect Dis 2001;33:562-569

23. Tong MJ, el-Farra NS, Reikes AR, Co RL. Clinical outcomes after transfusion associated hepatitis C. $\mathrm{N}$ Engl $\mathrm{J}$ Med 1995;332:1463-1466

24. Wiese M, Berr F, Lafrenz M, Porst H, Oesen U. Low frequency of cirrhosis in a hepatitis $\mathrm{C}$ (genotype $1 \mathrm{~b}$ ) single-source outbreak in Germany: a 20-year multicenter study. Hepatology 2000;32:91-96

25. Seeff L.B. Natural history of chronic hepatitis C. Hepatology 2002;36(5 Suppl 1):S35-S46

26. Thein HH, Yi Q, Dore GJ, Krahn MD. Estimation of stagespecific fibrosis progression rates in chronic hepatitis $\mathrm{C}$ virus infection: a meta-analysis and meta-regression. Hepatology 2008;48:418-431

27. Lawson A; on behalf of the Trent Hepatitis C Study Group. A comparison of the natural history and outcome of treatment for Asian and non-Asian hepatitis C-infected patients. J Viral Hepat 2011;18:e270-e277

28. Trinchet JC, Bourcier V, Chaffaut C, Ait Ahmed M, Allam S, Marcellin $\mathrm{P}$, et al. Complications and competing risks of death in compensated viral cirrhosis (ANRS CO12 CirVir prospective cohort). Hepatology 2015;62:737-750

29. Donato F, Boffetta P, Puoti M. A meta-analysis of epidemiological studies on the combined effect of hepatitis $\mathrm{B}$ and $\mathrm{C}$ virus infections in causing hepatocellular carcinoma. Int $\mathbf{J}$ Cancer 1998;75(3):347-354

30. Kiyosawa K. Trend of liver cirrhosis as precancerous lesions. Hepatol Res 2002;24:40-45

31. Bruno S, Crosignani A, Maisonneuve P, et al. Hepatitis $C$ virus genotype $1 \mathrm{~b}$ as a major risk factor associated with hepatocellular carcinoma in patients with cirrhosis: a seventeen-year prospective cohort study. Hepatology 2007;46:1350-1356

32. Ohki T, Tateishi R, Sato T, Masuzaki R, Imamura J, Goto T, Yamashiki N, Yoshida H, Kanai F, Kato N, Shiina S, Yoshida $\mathrm{H}$, Kawabe T, Omata M. Obesity is an independent risk factor for hepatocellular carcinoma development in chronic hepatitis $\mathrm{C}$ patients. Clin Gastroenterol Hepatol 2008;6:459-464

33. Bochud PY, Cai T, Overbeck K, Bochud M, Dufour JF, Mullhaupt B, Borovicka J, Heim M, Moradpour D, Cerny A, Malinverni R, Francioli P, Negro F. Genotype 3 is associated with 
accelerated fibrosis progression in chronic hepatitis C. J Hepatol 2009;51:655-666

34. De Nicola S, Aghemo A, Rumi MG, Colombo M. HCV genotype 3: an independent predictor of fibrosis progression in chronic hepatitis C. J Hepatol 2009;51:964-966

35. Nkontchou G, Ziol M, Aout M, Lhabadie M, Baazia Y, Mahmoudi A, Roulot D, Ganne-Carrie N, Grando-Lemaire V, Trinchet JC, Gordien E, Vicaut E, Baghad I, Beaugrand M. $\mathrm{HCV}$ genotype 3 is associated with a higher hepatocellular carcinoma incidence in patients with ongoing viral $\mathrm{C}$ cirrhosis. J Viral Hepat 2011;18:e516-e522

36. Kanwal F, Kramer JR, Ilyas J, Duan Z, El-Serag HB. HCV genotype 3 is associated with an increased risk of cirrhosis and hepatocellular cancer in a national sample of US veterans with HCV. Hepatology 2014;60:98-105

37. El-Serag HB, Kanwal F, Richardson P, Kramer J. Risk of hepatocellular carcinoma after sustained virologic response in veterans with HCV-infection. Hepatology 2016. doi: 10.1002/hep. 28535

38. Pinchoff J, Drobnik A, Bornschlegel K, et al. Deaths among people with hepatitis C in New York City, 2000-2011. Clin Infect Dis 2014;58:1047-1054

39. Mahajan R, Xing J, Liu SJ, et al. Mortality among persons in care with hepatitis $\mathrm{C}$ virus infection: the chronic hepatitis cohort study (CHeCS), 2006-2010. Clin Infect Dis 2014;58:1055-1061

40. Di Bisceglie AM, Stoddard AM, Dienstag JL, et al. Excess mortality in patients with advanced chronic hepatitis $\mathrm{C}$ treated with long-term peginterferon. Hepatology 2011;53:1100-1108

41. Fattovich G, Giustina G, Degos F, et al. Morbidity and mortality in compensated cirrhosis type C: a retrospective follow-up study of 384 patients. Gastroenterology 1997;112:463-472

42. Omland LH, Jepsen P, Krarup H, et al. Increased mortality among persons infected with hepatitis $\mathrm{C}$ virus. Clin Gastroenterol Hepatol 2011;9:71-78

43. Amin J, Law MG, Bartlett M, et al. Causes of death after diagnosis of hepatitis B or hepatitis C infection: a large community-based linkage study. Lancet 2006;368:938-945

44. Makara M, Sulyok M, Csacsovszki O, Sulyok Z, Vályi-Nagy I. Successful treatment of HCV-associated cryoglobulinemia with ombitasvir/paritaprevir/ritonavir, dasabuvir and ribavirin: A case report. J Clin Virol 2015;72:66-68

45. Gragnani L, Piluso A, Urraro T, Fabbrizzi A, Fognani E, Petraccia L, Genovesi A, Giubilei L, Ranieri J, Stasi C, Monti $\mathrm{M}$, Zignego AL. Virological and clinical response to interferonfree regimens in patients with HCV-related mixed cryoglobulinemia: preliminary results of a prospective pilot study. Curr Drug Targets 2016 (Epub ahead of print)

46. Mihm S, Fayyazi A, Hartmann H, Ramadori G. Analysis of histopathological manifestations of chronic hepatitis $\mathrm{C}$ virus infection with respect to virus genotype. Hepatology 1997;25:735-739

47. Rubbia-Brandt L, Quadri R, Abid K, Giostra E, Malé PJ, Mentha G, Spahr L, Zarski JP, Borisch B, Hadengue A, Negro F. Hepatocyte steatosis is a cytopathic effect of hepatitis $\mathrm{C}$ virus genotype 3. J Hepatol 2000;33:106-115

48. Sharma P, Balan V, Hernandez J, Rosati M, Williams J, Rodriguez-Luna H, Schwartz J, Harrison E, Anderson M, Byrne T, Vargas HE, Douglas DD, Rakela J. Hepatic steatosis in hepatitis $\mathrm{C}$ virus genotype 3 infection: does it correlate with body mass index, fibrosis, and HCV risk factors? Dig Dis Sci 2004;49:25-29

49. Hissar SS, Goyal A, Kumar M, Pandey C, Suneetha PV, Sood A, Midha V, Sakhuja P, Malhotra V, Sarin SK. Hepatitis C virus genotype 3 predominates in North and Central India and is associated with significant histopathologic liver disease. J Med Virol 2006;78:452-458
50. Kumar D, Farrell GC, Fung C, George J. Hepatitis C virus genotype 3 is cytopathic to hepatocytes: Reversal of hepatic steatosis after sustained therapeutic response. Hepatology 2002;36:1266-1272

51. Qiang G, Yang L, Witek RP, Jhaveri R. Recombinant adenoviruses expressing steatosis-associated hepatitis $\mathrm{C}$ virus genotype 3 core protein produce intracellular lipid accumulation in cultured and primary hepatocytes. Virus Res 2009;139:127-130

52. Jhaveri R, McHutchison J, Patel K, Qiang G, Diehl AM. Specific polymorphisms in hepatitis $\mathrm{C}$ virus genotype 3 core protein associated with intracellular lipid accumulation. J Infect Dis 2008;197:283-291

53. Ozyilkan E, Erbaş T, Simşek H, Telatar F, Kayhan B, Telatar H. Increased prevalence of hepatitis $\mathrm{C}$ virus antibodies in patients with diabetes mellitus. J Intern Med 1994;235:283-284

54. Simó R, Hernández C, Genescà J, Jardí R, Mesa J. High prevalence of hepatitis $\mathrm{C}$ virus infection in diabetic patients. Diabetes Care 1996;19:998-1000

55. Allison ME, Wreghitt T, Palmer CR, Alexander GJ. Evidence for a link between hepatitis $\mathrm{C}$ virus infection and diabetes mellitus in a cirrhotic population. J Hepatol 1994;21:1135-1139

56. Banerjee S, Saito K, Ait-Goughoulte M, Meyer K, Ray RB, Ray R. Hepatitis $\mathrm{C}$ virus core protein upregulates serine phosphorylation of insulin receptor substrate-1 and impairs the downstream akt/protein kinase B signaling pathway for insulin resistance. J Virol 2008;82:2606-2612

57. Bose SK, Shrivastava S, Meyer K, Ray RB, Ray R. Hepatitis C virus activates the mTOR/S6K1 signaling pathway in inhibiting IRS-1 function for insulin resistance. J Virol 2012;86:6315-6322

58. Di Bisceglie AM, Thompson J, Smith-Wilkaitis N, et al. Combination of interferon and ribavirin in chronic hepatitis $\mathrm{C}$ : retreatment of nonresponders to interferon. Hepatology 2001; 33:704-707

59. Shiffman ML, Diago M, Tran A, et al. Chronic hepatitis C in patients with persistently normal alanine transaminase levels. Clin Gastroenterol Hepatol 2006; 4:645-652

60. Puoti C, Bellis L, Guarisco R, Dell' Unto O, Spilabotti L, Costanza OM. HCV carriers with normal alanine aminotransferase levels: healthy persons or severely ill patients? Dealing with an everyday clinical problem. Eur $\mathrm{J}$ Intern Med 2010;21(2):57-61

61. Ghany MG, Lok AS, Everhart JE, et al. Predicting clinical and histologic outcomes based on standard laboratory tests in advanced chronic hepatitis C. Gastroenterology 2010;138:136-146

62. Bonis PA, Tong MJ, Blatt LM, et al. A predictive model for the development of hepatocellular carcinoma, liver failure, or liver transplantation for patients presenting to clinic with chronic hepatitis C. Am J Gastroenterol 1999;94:1605-1612

63. Khan MH, Farrell GC, Byth K, et al. Which patients with hepatitis C develop liver complications? Hepatology 2000;31:513-520

64. Watanabe H, Saito T, Shinzawa H, Okumoto K, Hattori E, Adachi T, et al. Spontaneous elimination of serum hepatitis $\mathrm{C}$ virus (HCV) RNA in chronic HCV carriers: a population-based cohort study. J Med Virol 2003;71:56-61

65. Marcellin P, Boyer N, Gervais A, Martinot M, Pouteau M, Castelnau $\mathrm{C}$, et al. Long-term histologic improvement and loss of detectable intrahepatic HCV RNA in patients with chronic hepatitis $\mathrm{C}$ and sustained response to interferon-alpha therapy. Ann Intern Med 1997;127:875-881

66. Poynard T, Moussalli J, Munteanu M, Thabut D, Lebray P, Rudler M, et al. Slow regression of liver fibrosis presumed by repeated biomarkers after virological cure in patients with chronic hepatitis C. J Hepatol 2013;59:675-683

67. Maylin S, Martinot-Peignoux M, Moucari R, Boyer N, Ripault MP, Cazals- Hatem D, et al. Eradication of hepatitis C virus in 
patients successfully treated for chronic hepatitis C. Gastroenterology 2008;135:821-829

68. Toccaceli F, Laghi V, Capurso L, Koch M, Sereno S, Scuderi M. Long-term liver histology improvement in patients with chronic hepatitis $\mathrm{C}$ and sustained response to interferon. J Viral Hepat 2003;10:126-133

69. Poynard T, McHutchison J, Manns M, Trepo C, Lindsay K, Goodman $\mathrm{Z}$, et al. Impact of pegylated interferon alfa- $2 \mathrm{~b}$ and ribavirin on liver fibrosis in patients with chronic hepatitis $\mathrm{C}$. Gastroenterology 2002;122:1303-1313

70. Shiratori Y, Imazeki F, Moriyama M, Yano M, Arakawa Y, Yokosuka O, et al. Histologic improvement of fibrosis in patients with hepatitis $\mathrm{C}$ who have sustained response to interferon therapy. Ann Intern Med 2000;132:517-524

71. Rincon D, Ripoll C, Lo Iacono O, Salcedo M, Catalina MV, Alvarez E, et al. Antiviral therapy decreases hepatic venous pressure gradient in patients with chronic hepatitis $\mathrm{C}$ and advanced fibrosis. Am J Gastroenterol 2006;101:2269-2274

72. Bruno S, Crosignani A, Facciotto C, Rossi S, Roffi L, Redaelli A, et al. Sustained virologic response prevents the development of esophageal varices in compensated, Child-Pugh class A hepatitis C virus-induced cirrhosis. A 12-year prospective follow-up study. Hepatology 2010;51:2069-2076

73. Cammà C, Di Bona D, Schepis F, Heathcote EJ, Zeuzem S, Pockros PJ, Marcellin P, Balart L, Alberti A, Craxì A. Effect of peginterferon alfa-2a on liver histology in chronic hepatitis C: a metaanalysis of individual patient data. Hepatology 2004;39:333-342

74. Everson GT, Balart L, Lee SS, Reindollar RW, Shiffman ML, Minuk GY, Pockros PJ, Govindarajan S, Lentz E, Heathcote EJ. Histological benefits of virological response to peginterferon alfa-2a monotherapy in patients with hepatitis $\mathrm{C}$ and advanced fibrosis or compensated cirrhosis. Aliment Pharmacol Ther 2008;27:542-551

75. Poynard T, McHutchison J, Manns M, et al. Impact of pegylated interferon alfa- $2 \mathrm{~b}$ and ribavirin on liver fibrosis in patients with chronic hepatitis C. Gastroenterology 2002;122(5):1303-1313

76. Maylin S, Martinot-Peignoux M, Moucari R, et al. Eradication of hepatitis $\mathrm{C}$ virus in patients successfully treated for chronic hepatitis C. Gastroenterology 2008;135:821-829

77. Schuppan D, Krebs A, Bauer M, et al. Hepatitis C and liver fibrosis. Cell Death Differ 2003;10(Suppl 1):S59-S67

78. Okanoue T, Itoh Y, Kirishima T, Daimon Y, Toyama T, Morita A, Nakajima T, Minami M. Transient biochemical response in interferon therapy decreases the development of hepatocellular carcinoma for five years and improves the long-term survival of chronic hepatitis C patients. Hepatol Res 2002;23:62-77

79. Yoshida H, Shiratori Y, Moriyama M, Arakawa Y, Ide T, Sata $\mathrm{M}$, et al. Interferon therapy reduces the risk for hepatocellular carcinoma: national surveillance program of cirrhotic and noncirrhotic patients with chronic hepatitis C in Japan. IHIT Study Group. Inhibition of Hepatocarcinogenesis by Interferon Therapy. Ann Intern Med 1999;131:174-181

80. Morgan TR, Ghany MG, Kim HY, Snow KK, Shiffman ML, De Santo JL, et al. Outcome of sustained virological responders with histologically advanced chronic hepatitis C. Hepatology 2010;52:833-844

81. Cardoso AC, Moucari R, Figueiredo-Mendes C, Ripault MP, Giuily N, Castelnau C, Boyer N, Asselah T, Martinot-Peignoux M, Maylin S, Carvalho-Filho RJ, Valla D, Bedossa P, Marcellin $\mathrm{P}$. Impact of peginterferon and ribavirin therapy on hepatocellular carcinoma: incidence and survival in hepatitis $\mathrm{C}$ patients with advanced fibrosis. J Hepatol 2010;52:652-657

82. Morgan RL, Baack B, Smith BD, Yartel A, Pitasi M, FalckYtter Y. Eradication of hepatitis $\mathrm{C}$ virus infection and the development of hepatocellular carcinoma: a meta-analysis of observational studies. Ann Intern Med 2013;158:329-337
83. Singal AK, Singh A, Jaganmohan S, Guturu P, Mummadi R, Kuo YF, Sood GK. Antiviral therapy reduces risk of hepatocellular carcinoma in patients with hepatitis $\mathrm{C}$ virus-related cirrhosis. Clin Gastroenterol Hepatol 2010;8:192-199

84. Di Marco V, Calvaruso V, Ferraro D, Bavetta MG, Cabibbo G, Conte E, et al. Effects of viral eradication in patients with HCV and cirrhosis differ with stage of portal hypertension. Gastroenterology 2016. doi:10.1053/j.gastro.2016.03.036

85. Chang KC, Hung $\mathrm{CH}$, Lu SN, Wang JH, Lee CM, Chen $\mathrm{CH}$, Yen MF, Lin SC, Yen YH, Tsai MC, Tseng PL, Hu TH. A novel predictive score for hepatocellular carcinoma development in patients with chronic hepatitis $\mathrm{C}$ after sustained response to pegylated interferon and ribavirin combination therapy. J Antimicrob Chemother 2012;67:2766-2772

86. Kasahara A, Tanaka H, Okanoue T, Imai Y, Tsubouchi H, Yoshioka K, Kawata S, Tanaka E, Hino K, Hayashi K, Tamura S, Itoh Y, Kiyosawa K, Kakumu S, Okita K, Hayashi N. Interferon treatment improves survival in chronic hepatitis $\mathrm{C}$ patients showing biochemical as well as virological responses by preventing liver-related death. J Viral Hepat 2004;11:148-156

87. Shiratori Y, Ito Y, Yokosuka O, Imazeki F, Nakata R, Tanaka N, Arakawa Y, Hashimoto E, Hirota K, Yoshida H, Ohashi Y, Omata M, Tokyo-Chiba Hepatitis Research Group. Antiviral therapy for cirrhotic hepatitis $\mathrm{C}$ : association with reduced hepatocellular carcinoma development and improved survival. Ann Intern Med 2005;142:105-114

88. WHO. Guidelines for the screening, care and treatment of persons with hepatitis infection. http://www.who.int/hiv/pub/hepa titis/hepatitis-c-guidelines/en/. Accessed 1 May 2016

89. Mohd Hanafiah K, Groeger J, Flaxman AD, Wiersma ST. Global epidemiology of hepatitis $\mathrm{C}$ virus infection: new estimates of age-specific antibody to HCV seroprevalence. Hepatology 2013;57:1333-1342

90. Breban R, Doss W, Esmat G, Elsayed M, Hellard M, Ayscue P, et al. Towards realistic estimates of HCV incidence in Egypt. J Viral Hepat 2013;20:294-296

91. Rao H, Wei L, Lopez-Talavera JC, Shang J, Chen H, Li J,et al. Distribution and clinical correlates of viral and host genotypes in Chinese patients with chronic hepatitis $\mathrm{C}$ virus infection. J Gastroenterol Hepatol 2014;29:545-553

92. Xu CJ, Zhang CP, Luo BF, Liu LJ, Wang YZ, Wang XH, et al. Prevalence and characterization of hepatitis $\mathrm{B}$ and $\mathrm{C}$ virus infections in a needle-sharing population in Northern China. BMC Public Health 2015;15:460

93. Torresi J, Johnson D, Wedemeyer H. Progress in the development of preventive and therapeutic vaccines for hepatitis $\mathrm{C}$ virus. J Hepatol 2011;54:1273-1285

94. Goldberg D, Anderson E. Hepatitis C: who is at risk and how do we identify them? J Viral Hepat 2004;11(Suppl 1):12-18

95. Lea T, Lee E, Mao L, de Wit J, Holt M. HIV and hepatitis C virus co-infection among men who have sex with men in Sydney, and associations with sexual and drug use practices. Sex Health 2013;10:448-451

96. Ishikane M, Watanabe K, Tsukada K, Nozaki Y, Yanase M, Igari T, et al. Acute hepatitis C in HIV-1 infected Japanese cohort: single center retrospective cohort study. PLoS One 2014;9:e100517

97. Lo YC, Tsai MS, Sun HY, Hung CC, Chuang JH. National trend and characteristics of acute hepatitis $\mathrm{C}$ among HIV-infected individuals: a matched case-control study-Taiwan, 2001-2014. PLoS One 2015;10:e139687

98. Vermeulen M, Lelie N, Sykes W, Crookes R, Swanevelder J, Gaggia L, et al. Impact of individual-donation nucleic acid testing on risk of human immunodeficiency virus, hepatitis B virus, and hepatitis $C$ virus transmission by blood transfusion in South Africa. Transfusion 2009;49:1115-1125 
99. Shan H, Ren FR, Zhao HY, Zhang YZ, Wen GX, Yao FZ, et al. A multi-Chinese blood center study testing serologic-negative donor samples for hepatitis $\mathrm{C}$ virus and human immunodeficiency virus with nucleic acid testing. Transfusion 2007;47:2011-2016

100. Roth WK, Busch MP, Schuller A, Ismay S, Cheng A, Seed CR, et al. International survey on NAT testing of blood donations: expanding implementation and yield from 1999 to 2009. Vox Sang 2012;102:82-90

101. Brojer E, Liszewski G, Niznik A, Rosiek A, Letowska M, Peterson JE, et al. Detection of HCV core antigen in HCV RNA positive, anti-HCV negative blood donations from Polish blood donors. Transfusion 2001;41:304

102. Laperche S, Le Marrec N, Girault A, Bouchardeau F, ServantDelmas A, Maniez-Montreuil M, et al. Simultaneous detection of hepatitis $\mathrm{C}$ virus (HCV) core antigen and anti-HCV antibodies improves the early detection of $\mathrm{HCV}$ infection. J Clin Microbiol 2005;43:3877-3883

103. Letowska M, Rosiek A, Gronowska A, Mikulska M, Grabarczyk $\mathrm{P}$, Brojer E. Hepatitis $\mathrm{C}$ virus (HCV) core antigen detection in HCV RNA-positive/anti-HCV-negative Polish blood donors identified by nucleic acid testing. Transfusion 2009;49:2241-2242

104. Prati D. Transmission of hepatitis $C$ virus by blood transfusions and other medical procedures: a global review. J Hepatol 2006;45:607-616

105. Global Database on Blood Safety. Summary Report 2011. http:// www.who.int/bloodsafety/global_database/en/. Accessed 1 May 2016

106. Simonsen L, Kane A, Lloyd J, Zaffran M, Kane M. Unsafe injections in the developing world and transmission of bloodborne pathogens: a review. Bull World Health Organ 1999;77:789-800

107. Hayashi J, Kishihara Y, Yamaji K, Yoshimura E, Kawakami Y, Akazawa $\mathrm{K}$, et al. Transmission of hepatitis $\mathrm{C}$ virus by health care workers in a rural area of Japan. Am J Gastroenterol 1995;90:794-799

108. Waheed Y, Shafi T, Safi SZ, Qadri I. HCV in Pakistani: a systematic review of prevalence genotypes and risk factors. World $\mathrm{J}$ Gastroenterol 2009;15:5647-5653

109. Janjua NZ, Hamza HB, Islam M, Tirmizi SF, Siddiqui A, Jafri $\mathrm{W}$, et al. Health care risk factors among women and personal behaviors among men explain the high prevalence of hepatitis $\mathrm{C}$ virus infection in Karachi, Pakistan. J Viral Hepat 2010;17:317-326

110. Kane A, Lloyd J, Zaff ran M, Simonsen L, Kane M. Transmission of hepatitis $\mathrm{B}$, hepatitis $\mathrm{C}$ and human immunodeficiency viruses through unsafe injections in the developing world: model-based regional estimates. Bull World Health Organ 1999;77:801-807

111. Hutin YJ, Hauri AM, Armstrong GL. Use of injections in healthcare settings worldwide, 2000: literature review and regional estimates. Br Med J 2003;327(7423):1075

112. Centers for Disease Control and Prevention. Recommendations for prevention and control of hepatitis $\mathrm{C}$ virus (HCV) infection and $\mathrm{HCV}$-related chronic disease. Morbidity and mortality weekly report 1998;47(No. RR-19):1-39

113. Prüss-Üstün A, Rapiti E, Hutin Y. Estimation of the global burden of disease attributable to contaminated sharps injuries among health-care workers. Am J Ind Med 2005;48:482-490

114. de Ledinghen V, Trimoulet P, Mannant PR, Dumas F, Champbenoit $\mathrm{P}$, Baldit $\mathrm{C}$, et al. Outbreak of hepatitis $\mathrm{C}$ virus infection during sclerotherapy of varicose veins: long-term follow-up of 196 patients (4535 patient-years). J Hepatol 2007;46:19-2560

115. Gutelius B, Perz JF, Parker MM, Hallack R, Stricof R, Clement EJ, et al. Multiple clusters of hepatitis virus infections associated with anesthesia for outpatient endoscopy procedures. Gastroenterology 2010;139:163-170

116. Patel PR, Larson AK, Castel AD, Ganova-Raeva LM, Myers RA, Roup BJ, et al. Hepatitis C virus infections from a contaminated radiopharmaceutical used in myocardial perfusion studies. JAMA 2006;296:2005-2011

117. Ross RS, Viazov S, Clauberg R, Wolters B, Fengler I, Eveld K, et al. Lack of de novo hepatitis $\mathrm{C}$ virus infections and absence of nosocomial transmissions of GB virus $\mathrm{C}$ in a large cohort of German haemodialysis patients. J Viral Hepat 2009;16:230-238

118. Mohamoud YA, Mumtaz GR, Riome S, Miller D, Abu-Raddad LJ. The epidemiology of hepatitis C virus in Egypt: a systematic review and data synthesis. BMC Infect Dis 2013;13:288.

119. Centers for Disease Control and Prevention (CDC). Infection control requirements for dialysis facilities and clarification regarding guidance on parenteral medication vials. MMWR Morb Mortal Wkly Rep 2008;57:875-876

120. Hosoglu S, Akalin S, Sunbul M, Otkun M, Ozturk R, Occupational Infections Study Group. Healthcare workers' compliance with universal precautions in Turkey. Med Hypotheses 2011;77:1079-1082

121. Megha K, Daksha P. Knowledge and practices about hospital waste disposal and universal safety precautions in class IV employee. J Commun Dis 2013;45:59-64

122. Luo Y, He GP, Zhou JW, Luo Y. Factors impacting compliance with standard precautions in nursing, China. Int $\mathbf{J}$ Infect Dis 2010;14:e1106-e1114

123. Timilshina N, Ansari MA, Dayal V. Risk of infection among primary health workers in the Western Development Region, Nepal: knowledge and compliance. J Infect Dev Ctries 2011;5:18-22

124. Hamid MZ, Aziz NA, Anita AR, Norlijah O. Knowledge of blood-borne infectious diseases and the practice of universal precautions amongst health-care workers in a tertiary hospital in Malaysia. Southeast Asian J Trop Med Public Health 2010;41:1192-1199

125. Earl CE. Thai nursing students' knowledge and health beliefs about AIDS and use of universal precautions: a cross-sectional descriptive research study. AAOHN J 2010;58:331-334

126. Hayes MO, Harkness GA. Body piercing as a risk factor for viral hepatitis: an integrative research review. Am J Infect Control 2001;29:271-274

127. Jafari S, Copes R, Baharlou S, Etminan M, Buxton J. Tattooing and the risk of transmission of hepatitis $\mathrm{C}$ : a systematic review and meta-analysis. Int J Infect Dis 2010;14:e928-e940

128. Nelson PK, Mathers BM, Cowie B, Hagan H, Des Jarlais D, Horyniak D, et al. Global epidemiology of hepatitis B and hepatitis $\mathrm{C}$ in people who inject drugs: results of systematic reviews. Lancet 2011;378:571-583

129. Palmateer N, Kimber J, Hickman M, Hutchinson S, Rhodes T, Goldberg D. Evidence for the effectiveness of sterile injecting equipment provision in preventing hepatitis $\mathrm{C}$ and human immunodeficiency virus transmission among injecting drug users: a review of reviews. Addiction 2010;105:844-859

130. Hagan H, Campbell JV, Thiede H, Strathdee SA, Ouellet L, Latka $\mathrm{M}$, et al. Injecting alone among young adult IDUs in five US cities: evidence of low rates of injection risk behavior. Drug Alcohol Depend 2007;91(Suppl 1):S48-S55

131. Mathers BM et al. HIV prevention, treatment, and care services for people who inject drugs: a systematic review of global, regional, and national coverage. Lancet 2010;375(9719):1014-1028

132. Scheinmann R, Hagan H, Lelutiu-Weinberger C, Stern R, Des Jarlais DC, Flom PL, et al. Non-injection drug use and hepatitis C virus: a systematic review. Drug Alcohol Depend 2007;89:1-12 
133. Terrault NA, Dodge JL, Murphy EL, Tavis JE, Kiss A, Levin TR, et al. Sexual transmission of hepatitis $C$ virus among monogamous heterosexual couples: the $\mathrm{HCV}$ partners study. Hepatology 2013;57:881-889

134. Tseng YT, Sun HY, Chang SY, Wu CH, Liu WC, Wu PY, et al. Seroprevalence of hepatitis virus infection in men who have sex with men aged 18-40 years in Taiwan. J Formos Med Assoc 2012;111:431-438

135. Price H, Gilson R, Mercey D, Copas A, Parry J, Nardone A, et al. Hepatitis $\mathrm{C}$ in men who have sex with men in London-a community survey. HIV Med 2013;14:578-580

136. Rauch A, Rickenbach M, Weber R, Hirschel B, Tarr PE, Bucher $\mathrm{HC}$, et al. Unsafe sex and increased incidence of hepatitis $\mathrm{C}$ virus infection among HIV-infected men who have sex with men: the Swiss HIV Cohort Study. Clin Infect Dis 2005;41:395-402

137. European Paediatric Hepatitis C Virus Network. A significant sex-but not elective cesarean section-effect on mother-to child transmission of hepatitis $\mathrm{C}$ virus infection. J Infect Dis 2005; $192: 1872-1879$

138. Thomas DL, Villano SA, Riester KA, Hershow R, Mofenson LM, Landesman SH, et al. Perinatal transmission of hepatitis C virus from human immunodeficiency virus type 1-infected mothers. Women and Infants Transmission Study. J Infect Dis 1998;177:1480-1488

139. Mast EE, Hwang LY, Seto DS, Nolte FS, Nainan OV, Wurtzel $\mathrm{H}$, et al. Risk factors for perinatal transmission of hepatitis $\mathrm{C}$ virus $(\mathrm{HCV})$ and the natural history of $\mathrm{HCV}$ infection acquired in infancy. J Infect Dis 2005;192:1880-1889

140. Ghamar Chehreh ME, Tabatabaei SV, Khazanehdari S, Alavian SM. Effect of cesarean section on the risk of perinatal transmission of hepatitis $\mathrm{C}$ virus from HCV-RNA?/HIV- mothers: a meta-analysis. Arch Gynecol Obstet 2011;283:255-260

141. Cottrell EB, Chou R, Wasson N, Rahman B, Guise JM. Reducing risk for mother-to-infant transmission of hepatitis $\mathrm{C}$ virus: a systematic review for the U.S. Preventive Services Task Force. Ann Intern Med 2013;158:109-113

142. Grebely J, Prins M, Hellard M, Cox AL, Osburn WO, Lauer G, et al. Hepatitis $\mathrm{C}$ virus clearance, reinfection, and persistence, with insights from studies of injecting drug users: towards a vaccine. Lancet Infect Dis 2012;12:408-414

143. Cunningham EB, Applegate TL, Lloyd AR, Dore GJ, Grebely J. Mixed HCV infection and reinfection in people who inject drugs-impact on therapy. Nat Rev Gastroenterol Hepatol 2015;12:218-230

144. Backmund M, Reimer J, Meyer K, Gerlach JT, Zachoval R. Hepatitis $\mathrm{C}$ virus infection and injection drug users: prevention, risk factors, and treatment. Clin Infect Dis 2005;40 (Suppl 5):S330-S335

145. Aspinall EJ, Corson S, Doyle JS, Grebely J, Hutchinson SJ, Dore GJ, et al. Treatment of hepatitis $\mathrm{C}$ virus infection among people who are actively injecting drugs: a systematic review and meta-analysis. Clin Infect Dis 2013;57 (Suppl 2):S80-S89

146. Grady BP, Schinkel J, Thomas XV, Dalgard O. Hepatitis C virus reinfection following treatment among people who use drugs. Clin Infect Dis 2013;57 (Suppl 2):S105-S110

147. Kwo PY, Mantry PS, Coakley E, Te HS, Vargas HE, Brown R $\mathrm{Jr}$, et al. An interferon-free antiviral regimen for HCV after liver transplantation. N Engl J Med 2014;371:2375-2382

148. Charlton M, Gane E, Manns MP, Brown RS Jr, Curry MP, Kwo $\mathrm{PY}$, et al. Sofosbuvir and ribavirin for treatment of compensated recurrent hepatitis $\mathrm{C}$ virus infection after liver transplantation. Gastroenterology 2015;148:108-117

149. Curry MP, Forns X, Chung RT, Terrault NA, Brown R Jr, Fenkel JM, et al. Sofosbuvir and ribavirin prevent recurrence of
HCV infection after liver transplantation: an open-label study. Gastroenterology 2015;148:100-107

150. Kamili S, Drobeniuc J, Araujo AC, Hayden TM. Laboratory diagnostics for hepatitis $\mathrm{C}$ virus infection. Clin Infect Dis 2012;55 (Suppl 1):S43-S48

151. Ghany MG, Strader DB, Thomas DL, Seeff LB, American Association for the Study of Liver D. Diagnosis, management, and treatment of hepatitis C: an update. Hepatology 2009; 49:1335-1374

152. Centers for Disease Control and Prevention. Testing for HCV infection: an update of guidance for clinicians and laboratorians. MMWR Morb Mortal Wkly Rep 2013;62:362-365

153. Shivkumar S, Peeling R, Jafari Y, Joseph L, Pant Pai N. Accuracy of rapid and point-of-care screening tests for hepatitis C: a systematic review and meta-analysis. Ann Intern Med 2012;157:558-566

154. Chevaliez S, Soulier A, Poiteau L, Bouvier-Alias M, Pawlotsky J. Clinical utility of hepatitis $\mathrm{C}$ virus core antigen quantification in patients with chronic hepatitis C. J Clin Virol 2014;61:145-148

155. Morishima C, Morgan TR, Everhart JE, Wright EC, Apodaca MC, Gretch DR, Shiffman ML, et al. Interpretation of positive transcription-mediated amplification test results from polymerase chain reaction-negative samples obtained after treatment of chronic hepatitis C. Hepatology 2008;48:1412-1419

156. Stramer SL, Krysztof DE, Brodsky JP, Fickett TA, Reynolds B, Dodd RY, Kleinman SH. Comparative analysis of triplex nucleic acid test assays in United States blood donors. Transfusion 2013;53:2525-2537

157. Lee MH, Lu SN, Yuan Y, Yang HI, Jen CL, You SL, Wang LY, et al. Development and validation of a clinical scoring system for predicting risk of $\mathrm{HCC}$ in asymptomatic individuals seropositive for anti-HCV antibodies. PLoS One 2014;9:e94760

158. Lee MH, Yang HI, Lu SN, Jen CL, Yeh SH, Liu CJ, Chen PJ, et al. Hepatitis $\mathrm{C}$ virus seromarkers and subsequent risk of hepatocellular carcinoma: long-term predictors from a community-based cohort study. J Clin Oncol 2010;28:4587-4593

159. Yu ML, Chuang WL. Treatment of chronic hepatitis C in Asia: when East meets West. J Gastroenterol Hepatol 2009;24:336-345

160. Huang CF, Huang JF, Yang JF, Hsieh MY, Lin ZY, Chen SC, Wang LY, et al. Interleukin-28B genetic variants in identification of hepatitis $\mathrm{C}$ virus genotype 1 patients responding to 24 weeks peginterferon/ribavirin. J Hepatol 2012;56:34-40

161. Kowdley KV, Gordon SC, Reddy KR, Rossaro L, Bernstein DE, Lawitz E, Shiffman ML, et al. Ledipasvir and sofosbuvir for 8 or 12 weeks for chronic HCV without cirrhosis. N Engl J Med 2014;370:1879-1888

162. Yu ML, Dai CY, Huang JF, Hou NJ, Lee LP, Hsieh MY, Chiu $\mathrm{CF}$, et al. A randomised study of peginterferon and ribavirin for 16 versus 24 weeks in patients with genotype 2 chronic hepatitis C. Gut 2007;56:553-559

163. Yu ML, Dai CY, Huang JF, Chiu CF, Yang YH, Hou NJ, Lee LP, et al. Rapid virological response and treatment duration for chronic hepatitis $\mathrm{C}$ genotype 1 patients: a randomized trial. Hepatology 2008;47:1884-1893

164. Di Martino V, Richou C, Cervoni JP, Sanchez-Tapias JM, Jensen DM, Mangia A, Buti M, et al. Response-guided peginterferon plus ribavirin treatment duration in chronic hepatitis C: meta-analyses of randomized, controlled trials and implications for the future. Hepatology 2011;54:789-800

165. Yu ML, Liu CH, Huang CF, Tseng TC, Huang JF, Dai CY, Lin $\mathrm{ZY}$, et al. Revisiting the stopping rule for hepatitis $\mathrm{C}$ genotype 1 patients treated with peginterferon plus ribavirin. PLoS One 2012;7:e52048

166. Pisani G, Cristiano K, Marino F, Luciani F, Bisso GM, Mele C, Adriani D, Gentili G, Wirz M. Quantification of hepatitis C 
virus (HCV) RNA in a multicenter study: implications for management of HCV genotype 1-infected patients. J Clin Microbiol 2009;47:2931-2936

167. Saldanha J, Lelie N, Heath A. Establishment of the first international standard for nucleic acid amplification technology (NAT) assays for HCV RNA. WHO Collaborative Study Group. Vox Sang 1999;76:149-158

168. Harrington PR, Zeng W, Naeger LK. Clinical relevance of detectable but not quantifiable hepatitis $\mathrm{C}$ virus RNA during boceprevir or telaprevir treatment. Hepatology 2012;55:1048-1057

169. Vermehren J, Yu ML, Monto A, Yao JD, Anderson C, Bertuzis R, Schneider G, et al. Multi-center evaluation of the Abbott RealTime HCV Assay for monitoring patients undergoing antiviral therapy for chronic hepatitis C. J Clin Virol 2011;52:133-137

170. Zitzer H, Heilek G, Truchon K, Susser S, Vermehren J, Sizmann $\mathrm{D}$, Cobb B, et al. Second-generation Cobas AmpliPrep/Cobas TaqMan HCV quantitative test for viral load monitoring: a novel dual-probe assay design. J Clin Microbiol 2013;51:571-577

171. Drexler JF, Reber U, Wuttkopf A, Eis-Hubinger AM, Drosten C. Performance of the novel Qiagen artus QS-RGQ viral load assays compared to that of the Abbott RealTime system with genetically diversified HIV and hepatitis C virus plasma specimens. J Clin Microbiol 2012;50:2114-2117

172. Pas S, Molenkamp R, Schinkel J, Rebers S, Copra C, SevenDeniz S, Thamke D, et al. Performance evaluation of the new Roche cobas AmpliPrep/cobas TaqMan HCV test, version 2.0, for detection and quantification of hepatitis $\mathrm{C}$ virus RNA. J Clin Microbiol 2013;51:238-242

173. Yu ML, Lee CM, Chen CL, Chuang WL, Lu SN, Liu CH, Wu $\mathrm{SS}$, et al. Sustained hepatitis $\mathrm{C}$ virus clearance and increased hepatitis B surface antigen seroclearance in patients with dual chronic hepatitis $\mathrm{C}$ and $\mathrm{B}$ during posttreatment follow-up. Hepatology 2013;57:2135-2142

174. Chen J, Florian J, Carter W, Fleischer RD, Hammerstrom TS, Jadhav PR, Zeng W, et al. Earlier sustained virologic response end points for regulatory approval and dose selection of hepatitis C therapies. Gastroenterology 2013;144:1450-1455

175. Yoshida EM, Sulkowski MS, Gane EJ, Herring RW, Jr., Ratziu $\mathrm{V}$, Ding X, Wang J, et al. Concordance of sustained virological response 4,12 , and 24 weeks post-treatment with sofosbuvircontaining regimens for hepatitis $\mathrm{C}$ virus. Hepatology 2015;61:41-45

176. Kanda T, Nakamoto S, Sasaki R, Nakamura M, Yasui S, Haga Y, Ogasawara S, Tawada A, Arai M, Mikami S, Imazeki F, Yokosuka O. Sustained virologic response at 24 weeks after the end of treatment is a better predictor for treatment outcome in real-world $\mathrm{HCV}$-infected patients treated by $\mathrm{HCV}$ NS3/4A protease inhibitors with peginterferon plus ribavirin. Int J Med Sci 2016;13:310-315

177. Yu M-L, Chuang W-L. New treatments for HCV: Perspective from Asia. Clin Liver Dis 2015;5:17-21

178. Smith DB, Bukh J, Kuiken C, Muerhoff AS, Rice CM, Stapleton JT, Simmonds P. Expanded classification of hepatitis C virus into 7 genotypes and 67 subtypes: updated criteria and genotype assignment web resource. Hepatology 2014;59:318-327

179. Gower E, Estes C, Blach S, Razavi-Shearer K, Razavi H. Global epidemiology and genotype distribution of the hepatitis $\mathrm{C}$ virus infection. J Hepatol 2014;61:S45-S57

180. Hsieh MH, Tsai JJ, Hsieh MY, Huang CF, Yeh ML, Yang JF, Chang $\mathrm{K}$, et al. Hepatitis $\mathrm{C}$ virus infection among injection drug users with and without human immunodeficiency virus co-infection. PLoS One 2014;9:e94791

181. Lenz O, Verbinnen T, Fevery B, Tambuyzer L, Vijgen L, Peeters M, Buelens A, et al. Virology analyses of HCV isolates from genotype 1-infected patients treated with simeprevir plus peginterferon/ribavirin in Phase IIb/III studies. J Hepatol 2015;62:1008-1014

182. Manns M, Pol S, Jacobson IM, Marcellin P, Gordon SC, Peng CY, Chang TT, et al. All-oral daclatasvir plus asunaprevir for hepatitis $\mathrm{C}$ virus genotype $1 \mathrm{~b}$ : a multinational, phase 3 , multicohort study. Lancet 2014;384:1597-1605

183. McPhee F, Suzuki Y, Toyota J, Karino Y, Chayama K, Kawakami Y, Yu ML, et al. High sustained virologic response to daclatasvir plus asunaprevir in elderly and cirrhotic patients with hepatitis C virus genotype $1 \mathrm{~b}$ without baseline NS5A polymorphisms. Adv Ther 2015;32:637-649

184. Ge D, Fellay J, Thompson AJ, Simon JS, Shianna KV, Urban TJ, Heinzen EL, et al. Genetic variation in IL28B predicts hepatitis C treatment-induced viral clearance. Nature 2009;461:399-401

185. Tanaka Y, Nishida N, Sugiyama M, Kurosaki M, Matsuura K, Sakamoto N, Nakagawa M, et al. Genome-wide association of IL28B with response to pegylated interferon-alpha and ribavirin therapy for chronic hepatitis C. Nat Genet 2009;41:1105-1109

186. Yu ML, Huang CF, Huang JF, Chang NC, Yang JF, Lin ZY, Chen SC, et al. Role of interleukin-28B polymorphisms in the treatment of hepatitis $\mathrm{C}$ virus genotype 2 infection in Asian patients. Hepatology 2011;53:7-13

187. Huang CF, Yeh ML, Hsieh MH, Hsieh MY, Lin ZY, Chen SC, Wang LY, et al. Clinical utility of host genetic IL-28B variants in hepatitis $\mathrm{C}$ virus genotype 1 Asian patients retreated with pegylated interferon plus ribavirin. J Gastroenterol Hepatol 2013;28:1515-1520

188. Afdhal N, Reddy KR, Nelson DR, Lawitz E, Gordon SC, Schiff E, Nahass R, et al. Ledipasvir and sofosbuvir for previously treated HCV genotype 1 infection. $N$ Engl J Med 2014;370:1483-1493

189. Poordad F, Hezode C, Trinh R, Kowdley KV, Zeuzem S, Agarwal K, Shiffman ML, et al. ABT-450/r-ombitasvir and dasabuvir with ribavirin for hepatitis $\mathrm{C}$ with cirrhosis. $\mathrm{N}$ Engl J Med 2014;370:1973-1982

190. Zeuzem S, Dusheiko GM, Salupere R, Mangia A, Flisiak R, Hyland RH, Illeperuma A, et al. Sofosbuvir and ribavirin in HCV genotypes 2 and 3. N Engl J Med 2014;370:1993-2001

191. Nelson DR, Cooper JN, Lalezari JP, Lawitz E, Pockros PJ, Gitlin N, Freilich BF, et al. All-oral 12-week treatment with daclatasvir plus sofosbuvir in patients with hepatitis $\mathrm{C}$ virus genotype 3 infection: ALLY-3 phase III study. Hepatology 2015;61:1127-1135

192. Shiha G, Sarin SK, Ibrahim AE, Omata M, Kumar A, Lesmana LA, Leung N, et al. Liver fibrosis: consensus recommendations of the Asian Pacific Association for the Study of the Liver (APASL). Hepatol Int 2009;3:323-333

193. Lin ZH, Xin YN, Dong QJ, Wang Q, Jiang XJ, Zhan SH, Sun Y, et al. Performance of the aspartate aminotransferase-to-platelet ratio index for the staging of hepatitis C-related fibrosis: an updated meta-analysis. Hepatology 2011;53:726-736

194. Singh S, Venkatesh SK, Wang Z, Miller FH, Motosugi U, Low $\mathrm{RN}$, Hassanein $\mathrm{T}$, et al. Diagnostic performance of magnetic resonance elastography in staging liver fibrosis: a systematic review and meta-analysis of individual participant data. Clin Gastroenterol Hepatol 2015;13:440-451:e446

195. Chou R, Wasson N. Blood tests to diagnose fibrosis or cirrhosis in patients with chronic hepatitis $\mathrm{C}$ virus infection: a systematic review. Ann Intern Med 2013;158:807-820

196. Sebastiani G, Halfon P, Castera L, Pol S, Thomas DL, Mangia A, Di Marco V, et al. SAFE biopsy: a validated method for large-scale staging of liver fibrosis in chronic hepatitis C. Hepatology 2009;49:1821-1827

197. Castera L, Sebastiani G, Le Bail B, de Ledinghen V, Couzigou $\mathrm{P}$, Alberti A. Prospective comparison of two algorithms 
combining non-invasive methods for staging liver fibrosis in chronic hepatitis C. J Hepatol 2010;52:191-198

198. Carrion JA, Torres F, Crespo G, Miquel R, Garcia-Valdecasas JC, Navasa M, Forns X. Liver stiffness identifies two different patterns of fibrosis progression in patients with hepatitis $\mathrm{C}$ virus recurrence after liver transplantation. Hepatology 2010;51:23-34

199. Vergniol J, Foucher J, Terrebonne E, Bernard PH, Bail BL, Merrouche W, et al. Noninvasive tests for fibrosis and liver stiffness predict 5-year outcomes of patients with chronic hepatitis C. Gastroenterology 2011;140:1970-1979

200. Poynard T, Vergniol J, Ngo Y, Foucher J, Munteanu M, Merrouche $\mathrm{W}$, Colombo $\mathrm{M}$, et al. Staging chronic hepatitis $\mathrm{C}$ in seven categories using fibrosis biomarker (FibroTest) and transient elastography (FibroScan(R)). J Hepatol 2014;60:706-714

201. Vergniol J, Boursier J, Coutzac C, Bertrais S, Foucher J, Angel $\mathrm{C}$, Chermak F, et al. Evolution of noninvasive tests of liver fibrosis is associated with prognosis in patients with chronic hepatitis C. Hepatology 2014;60:65-76

202. Yu ML, Lin SM, Chuang WL, Dai CY, Wang JH, Lu SN, Sheen IS, et al. A sustained virological response to interferon or interferon/ribavirin reduces hepatocellular carcinoma and improves survival in chronic hepatitis C: a nationwide, multicentre study in Taiwan. Antivir Ther 2006;11:985-994

203. Huang JF, Yu ML, Lee CM, Dai CY, Hou NJ, Hsieh MY, Wang $\mathrm{JH}$, et al. Sustained virological response to interferon reduces cirrhosis in chronic hepatitis C: a 1386-patient study from Taiwan. Aliment Pharmacol Ther 2007;25:1029-1037

204. van der Meer AJ, Veldt BJ, Feld JJ, Wedemeyer H, Dufour JF, Lammert F, Duarte-Rojo A, et al. Association between sustained virological response and all-cause mortality among patients with chronic hepatitis $\mathrm{C}$ and advanced hepatic fibrosis. JAMA 2012;308:2584-2593

205. Hsu YC, Ho HJ, Wu MS, Lin JT, Wu CY. Postoperative peginterferon plus ribavirin is associated with reduced recurrence of hepatitis $\mathrm{C}$ virus-related hepatocellular carcinoma. Hepatology 2013;58:150-157

206. Huang CF, Yeh ML, Tsai PC, Hsieh MH, Yang HL, Hsieh MY, Yang JF, et al. Baseline gamma-glutamyl transferase levels strongly correlate with hepatocellular carcinoma development in non-cirrhotic patients with successful hepatitis $\mathrm{C}$ virus eradication. J Hepatol 2014;61:67-74

207. Hung CH, Lee CM, Wang JH, Hu TH, Chen CH, Lin CY, Lu $\mathrm{SN}$. Impact of diabetes mellitus on incidence of hepatocellular carcinoma in chronic hepatitis $\mathrm{C}$ patients treated with interferon-based antiviral therapy. Int J Cancer 2011;128:2344-2352

208. Arase Y, Kobayashi M, Suzuki F, Suzuki Y, Kawamura Y, Akuta N, Kobayashi M, et al. Effect of type 2 diabetes on risk for malignancies includes hepatocellular carcinoma in chronic hepatitis C. Hepatology 2013;57:964-973

209. Yu ML, Lin SM, Lee CM, Dai CY, Chang WY, Chen SC, Lee $\mathrm{LP}$, et al. A simple noninvasive index for predicting long-term outcome of chronic hepatitis $\mathrm{C}$ after interferon-based therapy. Hepatology 2006;44:1086-1097

210. Asahina Y, Tsuchiya K, Nishimura T, Muraoka M, Suzuki Y, Tamaki N, Yasui Y, et al. Alpha-fetoprotein levels after interferon therapy and risk of hepatocarcinogenesis in chronic hepatitis C. Hepatology 2013;58:1253-1262

211. Kanda T, Imazeki F, Mikami S, Kato K, Shimada N, Yonemitsu $\mathrm{Y}$, et al. Occurrence of hepatocellular carcinoma was not a rare event during and immediately after antiviral treatment in Japanese HCV-positive patients. Oncology 2011;80(5-6):366-372

212. Webster DP, Klenerman P, Dusheiko GM. Hepatitis C. Lancet 2015;385:1124-1135

213. Manns M, Forns X, Samuel D, Denning J, Arterburn S, BrandtSarif T, et al. Ledipasvir/Sofosbuvir with ribavirin is safe and efficacious in decompensated and post liver transplantation patients with $\mathrm{HCV}$ infection. Preliminary results of the prospective SOLAR 2 trial. J Hepatol 2015;62:S187

214. Omata M, Nishiguchi S, Ueno Y, Mochizuki H, Izumi N, Ikeda F, Toyoda H, Yokosuka O, Nirei K, Genda T, Umemura T, Takehara T, Sakamoto N, Nishigaki Y, Nakane K, Toda N, Ide T, Yanase M, Hino K, Gao B, Garrison KL, Dvory-Sobol H, Ishizaki A, Omote M, Brainard D, Knox S, Symonds WT, McHutchison JG, Yatsuhashi H, Mizokami M. Sofosbuvir plus ribavirin in Japanese patients with chronic genotype $2 \mathrm{HCV}$ infection: an open-label, phase 3 trial. J Viral Hepat 2014;21:762-768

215. Mizokami M, Yokosuka O, Takehara T, Sakamoto N, Korenaga M, Mochizuki H, Nakane K, Enomoto H, Ikeda F, Yanase M, Toyoda H, Genda T, Umemura T, Yatsuhashi H, Ide T, Toda N, Nirei K, Ueno Y, Nishigaki Y, Betular J, Gao B, Ishizaki A, Omote M, Mo H, Garrison K, Pang PS, Knox SJ, Symonds WT, McHutchison JG, Izumi N, Omata M. Ledipasvir and sofosbuvir fixed-dose combination with and without ribavirin for 12 weeks in treatment-naive and previously treated Japanese patients with genotype 1 hepatitis C: an open-label, randomised, phase 3 trial. Lancet Infect Dis 2015;15:645-653

216. Tanser F, Bärnighausen T, Grapsa E, Zaidi J, Newell ML. High coverage of ART associated with decline in risk of HIV acquisition in rural KwaZulu-Natal, South Africa. Science 2013;339:966-971 